\title{
Evaluation of the antitumor activity of NOV202, a novel microtubule targeting and vascular disrupting agent
}

This article was published in the following Dove Press journal:

Drug Design, Development and Therapy

28 April 2017

Number of times this article has been viewed

\section{Linda Rickardson \\ Emma Kutvonen ${ }^{2}$ \\ Satu Orasniemi ${ }^{2}$ \\ Marita Högberg' \\ Marko J Kallio ${ }^{2,3}$ \\ Stefan Rehnmark'}

'Noviga Research AB, Södertälje, Sweden; ${ }^{2}$ Department of Physiology, Institute of Biomedicine, University of Turku, ${ }^{3}$ Centre for Biotechnology, University of Turku, Turku, Finland

Correspondence: Stefan Rehnmark Noviga Research AB, Biovation Park, Forskargatan 20], I5I 36 Södertälje, Sweden

Tel +46736478842

Email stefan.rehnmark@novigaresearch. com
Purpose: Overall, $\sim 65 \%$ of patients diagnosed with advanced ovarian cancer (OC) will relapse after primary surgery and adjuvant first-line platinum- and taxane-based chemotherapy. Significant improvements in the treatment of OC are expected from the development of novel compounds having combined cytotoxic and antiangiogenic properties that make them effective on refractory tumors.

Methods: Permeability of NOV202 was determined with Caco-2 monolayer assay. The compound's pharmacokinetic profile and plasma:brain distribution were assessed in male C57B1/6 mice. The compound's impacts on tubulin, microtubules and cell cycle were investigated by using in vitro tubulin polymerization assay, cell-based immunofluorescence and live cell microscopy. The $\mathrm{IC}_{50}$ concentrations of NOV202 were assessed in a panel of eight cancer cell lines. Impact of the compound on vascular tube formation was determined using the StemKit and Chick chorioallantoic membrane assays. The in vivo efficacy of the compound was analyzed with an OC xenograft mouse model.

Results: NOV202 was found to suppress cancer cell proliferation at low nanomolar concentrations ( $\left.\mathrm{IC}_{50} 2.3-12.0 \mathrm{nM}\right)$ and showed equal efficacy between OC cell line $\mathrm{A} 2780\left(\mathrm{IC}_{50} 2.4 \mathrm{nM}\right)$ and its multidrug-resistant subline A2780/Adr $\left(\mathrm{IC}_{50} 2.3 \mathrm{nM}\right)$. Mechanistically, NOV202 targeted tubulin polymerization in vitro in a dose-dependent manner and in cells induced an $\mathrm{M}$ phase arrest. In vivo, NOV202 caused a dose-dependent reduction of tumor mass in an A2780 xenograft model, which at the highest dose $(40 \mathrm{mg} / \mathrm{kg})$ was comparable to the effect of paclitaxel (24 mg/kg). Interestingly, NOV202 exhibited vascular disrupting properties that were similar to the effects of Combretastatin A4.

Conclusion: NOV202 is a novel tubulin and vascular targeting agent that shows strong anticancer efficacy in cells and OC xenograft models. The finding that the compound induced significantly more cell death in Pgp/MDR1 overexpressing OC cells compared to vincristine and paclitaxel warrants further development of the compound as a new therapy for OC patients with treatment refractory tumors and/or relapsing disease.

Keywords: ovarian cancer, NOV202, microtubule-targeting agent, vascular disruption, M phase arrest, multidrug resistance

\section{Introduction}

Ovarian cancer (OC) is the leading cause of death among all gynecologic cancers. About $1.3 \%$ of women will develop the disease during their life and currently the 5 -year survival rate for all types of OC is $\sim 4 \% .^{1}$ It should be noted that in patients with advanced disease (ie, stages III-IV), the 5 -year survival rate is $<30 \%$. Despite many cancer drug innovations and clinical studies, the treatment of OC patients has not 
improved substantially over the last decade. Another factor that has overshadowed the therapeutic advancement is the fact that the origin and pathogenesis of OC remain poorly understood. The three main primary OC groups are epithelial, sex cord/stromal and germ cell tumors, of which the first group accounts for $\sim 90 \%$ of all cases. ${ }^{2}$ However, according to the recent morphological, molecular biology and genetic data, OC is a heterogeneous disease composed of different subtypes of tumors exhibiting dissimilar clinicopathologic features and tumorigenic behavior. Due to this diversity, it is not surprising that even new targeted adjuvant therapies such as vascular endothelial growth factor (VEGF) and EGFR pathway inhibitors have shown limited improvement to the overall OC survival rate. This emphasizes the clinical need for potent cytotoxic agents in the treatment of OC, as well as novel combinations of cytotoxic agents with biologics (eg, checkpoint inhibitors and anti-VEGF therapeutics) to improve therapeutic outcome.

Taxanes, together with vinca alkaloids and epothilones, belong to the group of tubulin targeting agents that exert their antitumor activity by causing perturbation of microtubule dependent cellular reactions. ${ }^{3}$ Besides induction of cell cycle arrest and cell death, many of these drugs also have antivascular actions that likely contribute to their clinical efficacy. ${ }^{4}$ Critically, these agents alter the microtubule dynamics in all cells of the body, which causes significant dose-limiting toxicities on normal tissues. ${ }^{3}$ Regardless of their adverse effects, today throughout the world, the standard of care in $\mathrm{OC}$ encompasses cytoreductive surgery followed by the administration of paclitaxel/docetaxel-platinum-based chemotherapy. ${ }^{5}$ Moreover, taxanes are also used as part of combination chemotherapy for the treatment of breast and nonsmall cell lung cancers. ${ }^{6,7}$ Importantly, despite that about two-thirds of OC patients initially respond to the combined surgery-chemotherapy treatment of $\sim 70 \%$ relapse at a median of 15 months from the original diagnosis. ${ }^{8}$ Moreover, the subsequent chemotherapy regimens typically fail due to the intrinsic and acquired chemoresistance. One contributing factor for tumor recurrence, metastasis and drug insensitivity is the fact that most of the women with OC are diagnosed at an advanced stage of the disease when the tumor aggressiveness is increased. ${ }^{9}$ Therefore, an urgent medical need exists for improved early detection of OC and development of more effective new therapies for the treatment of refractory tumors and relapsing disease.

One characteristic mechanism behind the acquired drug resistance is an accelerated drug efflux because of the enhanced expression of ATP binding cassette (ABC) transporter proteins, such as P-glycoprotein, Pgp/ABCB1/
MDR1. ${ }^{10,11}$ The known substrates of ABC transporter proteins include many cytotoxic drugs, such as taxanes, vinca alkaloids, anthracyclines, actinomycin $\mathrm{D}$ and mitomycin C. ${ }^{12,13}$ To overcome this serious clinical problem a number of strategies can be considered. For example, the therapeutic effects of existing drugs may be enhanced by combining them with the next generation Pgp inhibitors under development. ${ }^{14}$ Alternatively, adjustment of the clinical concentration of the drug-of-choice to counteract the kinetic parameters of Pgp-mediated efflux can improve the therapy outcome. ${ }^{15}$ Finally, the development of novel anticancer compounds that escape the efflux pump is expected to lead to better treatment results. Here, we describe the characteristics and antitumor activity of a novel microtubule depolymerizing and vascular disrupting agent, NOV202, that exhibits significant cell proliferation suppressive effects in OC xenograft models and in cultured cancer cell lines, including a multidrug-resistant subline.

\section{Materials and methods Compounds}

NOV202 (MW 413), synthesized at SP Process Development AB (Södertälje, Sweden), was used at a concentration range of $0.1 \mathrm{nM}-10.0 \mu \mathrm{M}$ depending on the assay. Paclitaxel (0.1 nM-3.0 $\mu \mathrm{M}$; Selleckchem, Houston, TX, USA), vincristine (0.1 nM-3.0 $\mu \mathrm{M}$; Selleckchem), vinblastine (5.0 nM-3.0 $\mu \mathrm{M}$; Selleckchem), lexibulin (CYT997) (0.1 nM-3.0 $\mu \mathrm{M}$, Selleckchem), Combretastatin A4 (0.8-50 nM; Selleckchem) and epothilone-B (5.0 nM-3.0 $\mu \mathrm{M}$; Selleckchem) were used as reference compounds. All compounds were dissolved into dimethyl sulfoxide (DMSO, max $0.1 \%$ of the total volume).

\section{Reagents and animals}

All reagents are from Sigma-Aldrich Corp. (St Louis, MO, USA) unless otherwise noted. Rj:NMRI-Foxn1nu/ Foxn1nu female mice (Janvier Laboratories, St Berthevin Cedex, France) were used in the maximal tolerated dose and xenograft assays, and $\mathrm{C} 57 \mathrm{Bl} / 6$ male mice (Taconic Biosciences Inc., Ejby, Denmark) were used in the pharmacokinetic study. All animal assays and handling were approved by and conducted in compliance with the policies of the Institutional animal care committees of the Experimental Pharmacology \& Oncology Berlin-Buch GmbH (Berlin, Germany) and In Vivo Design AB (Uppsala, Sweden) that fully meet the ethical and legal requirements as defined in the 2010/63/EU directive and national animal protection laws of German and Sweden. All mice were housed under strictly controlled and standardized barrier conditions $\left(22^{\circ} \mathrm{C} \pm 1^{\circ} \mathrm{C}\right.$ 
temperature, $50 \% \pm 10 \%$ relative humidity, $12 \mathrm{~h}$ light/dark rhythm) in individually ventilated Macrolon Type-II cages (Techniplast S.p.A., Buguggiate, Italy). The mice received autoclaved food (pellet chow) and acidified ( $\mathrm{pH} 4.0$ ) drinking water ad libitum.

\section{Cell culture}

The following cell lines and culture medium (indicated inside the brackets) were used in the study. The leukemia cell line CCRF-CEM (RPMI 1640), the ovarian carcinoma cell lines A2780 and A2780/Adr (RPMI 1640), the pancreatic adenocarcinoma cell line BXPC-3 (RPMI 1640), the lymphoma cell line U-937 (RPMI 1640), the myeloma cell line RPMI 8226 (RPMI 1640) and the colon carcinoma cell lines HT29 (McCoy's medium) and HCT116 (McCoy's medium) were purchased from European Collection of Cell Cultures (ECACC, Salisbury, UK). The bone metastatic breast adenocarcinoma cell line MDA-MB-231-SA (Dulbecco's Modified Eagle's Medium [DMEM]), the nontumorigenic breast luminal epithelial cell line MCF-10A (DMEM:HAM's F12, 1:1), the human intestinal Caco-2 cell line (EMEM), and the ovarian adenocarcinoma cell lines OvCar-8 (RPMI 1640), OvCar-4 (RPMI 1640) and CaOv-3 (DMEM) were purchased from the American Type Culture Collection (Manassas, VA, USA). The media were supplemented with $10 \%$ fetal bovine serum (FBS), glutamine (Sigma-Aldrich Corp.) and penicillin/streptomycin (Sigma-Aldrich Corp.), except for the MDA-MB-231-SA where 5\% horse serum and for Caco-2 20\% FBS were used. The cells were maintained in a humidified atmosphere at $37^{\circ} \mathrm{C}, 5 \% \mathrm{CO}_{2}$ and subcultured twice a week. For experiments, a density of $1,000-2,500$ or 5,000-10,000 cells per well were seeded in 384-well or 96-well microplates, respectively, depending on the assay.

\section{Pharmacokinetics and distribution}

The pharmacokinetics and distribution of NOV202 were determined in male $\mathrm{C} 57 \mathrm{Bl} / 6$ mice after intravenous (IV) $(10 \mathrm{mg} / \mathrm{kg}$, EtOH and 10\% Tween 80 in $5 \%$ glucose in water) and oral (PO) (30 mg/kg, 70\% PEG400, 0.25\% Tween) administrations at $0,0.5,1,2,4,6$ and 24 h postdosing. Blood samples were collected from three animals (tail vein or orbital sinus) per group in ethylenediaminetetraacetic acid-coated collection tubes (Sarstedt AB, Helsingborg, Sweden) and plasma was separated by centrifugation at $2,000 \times g$ for $5 \mathrm{~min}$. Plasma samples were stored in $-80^{\circ} \mathrm{C}$ until transportation on dry ice. In the pharmacokinetics study, the actual concentration was determined to 9.5 and $28.6 \mathrm{mg} / \mathrm{kg}$ for IV and $\mathrm{PO}$, respectively.

\section{Caco-2 permeability assay}

For determination of NOV202 permeability, Caco- 2 cell monolayers were grown to confluence on collagen-coated, microporous, polycarbonate membranes in 12-well transwell plates (Corning Inc., New York, USA). The permeability assay buffer was Hanks Balanced Salt Solution containing $10 \mathrm{mM}$ 4-(2-hydroxyethyl)-1-piperazineethanesulfonic acid (HEPES) and $15 \mathrm{mM}$ glucose at $\mathrm{pH}$ 7.4. The buffer in the receiver chamber also contained $1 \%$ bovine serum albumin. The dosing solution concentration was $5 \mu \mathrm{M}$ test compound in the assay buffer. Cell monolayers were dosed on the apical side (A-to-B) or basolateral side (B-to-A) and incubated at $37^{\circ} \mathrm{C}$ with $5 \% \mathrm{CO}_{2}$ in a humidified incubator. Samples were taken from the donor and receiver chambers at $120 \mathrm{~min}$. Each determination was performed in duplicate. The coapplied Lucifer yellow flux was also measured for each monolayer to out rule any cell monolayer damage during the flux period. All samples were assayed by liquid chromatography-mass spectrometry and tandem mass spectrometry using electrospray ionization.

The apparent permeability, $\mathrm{P}_{\mathrm{app}}$, and percent recovery were calculated as follows:

$$
\mathrm{P}_{\text {app }}=(d \mathrm{Cr} / d \mathrm{t}) \times \mathrm{V}_{\mathrm{r}} /\left(\mathrm{A} \times \mathrm{C}_{\mathrm{A}}\right),
$$

where $d \mathrm{Cr} / d \mathrm{t}$ is the slope of the cumulative concentration in the receiver compartment versus time in $\mu \mathrm{M} / \mathrm{s} ; \mathrm{V}_{\mathrm{r}}$ is the volume of the receiver compartment in $\mathrm{cm}^{3}$; $\mathrm{A}$ is the area of the insert (1.13 $\mathrm{cm}^{2}$ for 12 -well plate); $\mathrm{C}_{\mathrm{A}}$ is the average of the nominal dosing concentration and the measured $120 \mathrm{~min}$ donor concentration in $\mu \mathrm{M}$.

Interpretations of the results were done based on the following thresholds: Permeability classification: $\left(\mathrm{P}_{\text {app }}\right.$ A-to-B) $<1.0 \times 10^{-6} \mathrm{~cm} / \mathrm{s}$ : low; $\left(\mathrm{P}_{\text {app }}\right.$ A-to-B $) \geq 1.0 \times 10^{-6} \mathrm{~cm} / \mathrm{s}$ : high. Significant efflux: efflux ratio $>3.0$ and $\left(\mathrm{P}_{\mathrm{app}}\right.$ B-to-A) $\geq 1.0 \times 10^{-6} \mathrm{~cm} / \mathrm{s}$.

\section{In vitro tubulin polymerization assay}

NOV202 $(1.0-10 \mu \mathrm{M})$ was tested in a tubulin polymerization assay kit purchased from Cytoskeleton Inc. (Denver, CO, USA). Polymerization is followed by fluorescence enhancement due to the incorporation of a fluorescent reporter into microtubules as polymerization occurs. Vincristine and paclitaxel at $3.0 \mu \mathrm{M}$ were used as positive controls for tubulin polymerization inhibition and stabilization, respectively. All compounds were dissolved in DMSO and further diluted with sterile water to obtain a maximum DMSO concentration of $0.1 \%$, which was used as solvent control. NOV202 and control compounds were incubated 
with bovine tubulin protein in a cell-free environment and the fluorescence was then measured continuously using Fluostar Optima (BMG Labtech GmbH, Ortenberg, Germany) at $360 / 450 \mathrm{~nm}$ for $60 \mathrm{~min}$.

\section{Vascular tube formation assay}

Concentration dependent vascular tube formation induced by VEGF and tube disruption (cord length, $\mathrm{mm} / \mathrm{mm}^{2}$ ) were estimated using the StemKit (Essen BioScience Inc., Ann Arbor, MI, USA) and IncuCyte FLR (Essen BioScience) according to the manufacturer's procedure.

In short, cocultures of GFP-labeled endothelial colony forming cells (ECFCs) and adipocyte derived stem cells (ADSCs) were created on 96-well assay plates. Compound studies were performed using a concentration range of 0.046-100 nM for NOV202 and 0.78-100 nM for the reference compound Combretastatin A4, a tubulin inhibitor and vascular disrupting agent currently in phase III clinical trials. The neoangiogenic (cord formation) assay was initiated on day 0 by coapplying the compounds with VEGF $(20 \mathrm{ng} / \mathrm{mL})$. For determination of disruption of the established cords, VEGF (20 ng/mL) was applied alone on day 0 to form cord networks and 4 days later the compounds were administrated in the continued presence of VEGF (20 ng/mL). Cord formation/disruption was monitored kinetically using IncuCyte live cell imaging system. Fluorescent and phase-contrast images $(10 \times)$ were gathered every $6 \mathrm{~h}$ for up to 8 days and analyzed for cord length and number of branch points from 3 to 6 separate samples for each treatment condition.

\section{The chicken embryo chorioallantoic membrane (CAM) assay}

An ex ovo chicken embryo CAM assay was used to evaluate the compound's impact on angiogenesis. ${ }^{16}$ In short, fertilized chicken eggs from a local commercial hatchery were incubated in an automated incubator at $37.5^{\circ} \mathrm{C}$ and $60 \%$ humidity. On incubation day 4 , the eggs were broken gently to individual $10 \mathrm{~cm}$ petri dishes and incubated further. Two days later a small sterile filter paper ( $5 \mathrm{~mm}$ diameter) containing the experimental solution was placed on the CAM between two main blood vessels. The following drug concentrations, selected on the basis of a pilot test, were used; NOV202 (10, 50 and $200 \mathrm{nM})$ and Combretastatin A4 (10 and $50 \mathrm{nM}$ ). DMSO served as a negative control. The eggs were further incubated for 2 days and the blood vessel growth and integrity was recorded with a digital camera at 0,24 and $48 \mathrm{~h}$ time points. The relative surface area (vasculature growth) of vessels touching the filter paper and their relative disruption index (amount of intact vessel segments longer than $10 \mathrm{~mm}$ ) were measured from the photographs using the Metamorph software (Molecular Devices LLC, Sunnyvale, CA, USA).

\section{Cytotoxicity assay}

The fluorometric microculture cytotoxicity assay (FMCA) was used for the measurement of the cytotoxic and/or antiproliferative effect of compounds in vitro. ${ }^{17}$ For the experiments, 96- or 384-well microplates (Thermo Fisher Scientific, Waltham, MA, USA) were prepared with test compounds and stored at $-20^{\circ} \mathrm{C}$ or $-80^{\circ} \mathrm{C}$ until use. Cells were then seeded into the drug-prepared plates that were placed in an incubator for $72 \mathrm{~h}$. On the last day of incubation, the plates were washed, and a buffer containing fluorescein diacetate was added and incubated with the cells for $45 \mathrm{~min}$. The fluorescence per well was measured in a FLUOStar Optima (BMG Labtech GmbH) and a survival index \% (SI) for each compound-treated well was calculated with the equation: Compound-treated cells minus blank divided by control cells minus blank. From the SI, graphs were plotted using GraphPadPrism 5.0 (GraphPad Software Inc., San Diego $\mathrm{CA}, \mathrm{USA}$ ) and $\mathrm{IC}_{50}$-values for each cell type and compound were determined from the curves.

\section{Live cell microscopy}

Cells treated with NOV202 (3.0 and $50 \mathrm{nM})$, or reference drug paclitaxel (5.0 and $50 \mathrm{nM})$, vinblastine (5.0 and $50 \mathrm{nM}$ ) or epothilone ( 5.0 and $50 \mathrm{nM}$ ), were filmed in three replicates with IncuCyte live cell imager (Essen BioScience) using $1 \mathrm{~h}$ interval for a total of $72 \mathrm{~h}$ after adding the compounds on cells. The IncuCyte images were used for generating timelapse films and growth curves (the average cell confluence from six images per each time point). Time-lapse films were used for determining the duration of mitosis (10 cells per well, 30 cells per a treatment condition). Moreover, the fate of each mitotic cell that was used to calculate the length of cell division was recorded. Also the cell death index (CDI) was determined at 24 and $48 \mathrm{~h}$ time points.

\section{Immunofluorescence labeling}

Cells were grown on coverslips in 12-well plates until optimal cell confluence was obtained. Drugs were premixed with culture medium and added to cells for 24 or $48 \mathrm{~h}$. The following drug concentrations were selected on the basis of a pilot test and were used in further assays; NOV202 $(10-50 \mathrm{nM})$, paclitaxel $(5.0-50 \mathrm{nM})$, vinblastine $(5.0-50 \mathrm{nM})$ and epothilone-B (5.0-50 nM). The cells on coverslips were fixed for $15 \mathrm{~min}$ in $60 \mathrm{mM}$ Pipes, $\mathrm{pH}$ 6.9, $25 \mathrm{mM}$ HEPES, 
$10 \mathrm{mM}$ ethylene glycol tetraacetic acid, $4 \mathrm{mM} \mathrm{MgSO}_{4}$ containing $2 \%$ paraformaldehyde, $0.2 \%$ glutaraldehyde and $0.5 \%$ Triton X-100. The coverslips were rinsed in $10 \mathrm{mM} \mathrm{3-}(\mathrm{N}-$ morpholino)propanesulfonic acid, $\mathrm{pH} 7.4,150 \mathrm{mM} \mathrm{NaCl}$, $0.05 \%$ Tween-20 (MBST), and blocked for overnight in 20\% boiled normal goat serum in MBST. Cells were stained for $1 \mathrm{~h}$ at room temperature (RT) in 5\% goat serum in MBST containing primary antibodies against pericentrin (ab4448, 1:500; Abcam, Cambridge, UK) and alpha-tubulin (ab7291, 1:300; Abcam) followed by Alexa Fluor 488 and 555 dyes against mouse and rabbit antigens (Thermo Fisher Scientific) diluted $1: 400$ in MBST with 5\% goat serum. DNA was counter stained $10 \mathrm{~min}$ at RT with 4',6-diamidino-2-phenylindole ( $50 \mathrm{ng} / \mathrm{mL}$ in $\mathrm{H}_{2} \mathrm{O}$ ) before mounting in Vectashield (Vector laboratories, Burlingame, CA, USA).

\section{Fluorescence microscopy, image capture and analysis}

To visualize the microtubules, pericentrin and DNA, images were acquired using ScanR microscope (Olympus Corp., Tokyo, Japan) equipped with a Hamamatsu ORCA-ER CCD digital camera (Hamamatsu Photonics, Hamamatsu City, Japan). Image stacks (10 layers at $1.0 \mu \mathrm{m}$ step size) were captured using a $20 \times$ objective. The mitotic index (MI) was quantitated in a population of a minimum of 500 cells per treatment condition. Higher resolution images were acquired using Zeiss Axiovert $200 \mathrm{M}$ microscope (Carl Zeiss Corp., Oberkochen, Germany) equipped with a Hamamatsu ORCA-ER CCD camera (Hamamatsu Photonics) and Metamorph image analysis software (Molecular Devices). Image stacks (15-35 layers at 0.2-1.0 $\mu \mathrm{m}$ step size) were captured using a $63 \times$ oil immersion objective. Image stack was converted to maximum projections before the analysis of cell morphology.

\section{Human $O C$ cell xenograft study}

A study of the maximal tolerated dose of the NOV202 in NMRI nu/nu female mice was performed before the xenograft study. The plasma levels of NOV202 were determined after PO administration at 1 and $4 \mathrm{~h}$ post-dosing. For xenografts, 8 weeks old NMRI nu/nu female nude mice were used as follows; 8 animals in the vehicle group, 6 animals in each dose group of NOV202 and 6 animals in the paclitaxel group. For tumor establishment A2780 cells (passage 5) were inoculated subcutaneously and the tumors were allowed to reach a size of ca. $0.08 \mathrm{~mm}^{3}$ (typically by the study day 8) prior to start of the treatments. NOV202 was administered PO at 3 different doses $(10,20$ and $40 \mathrm{mg} / \mathrm{kg})$ in a 5 days treatment and 2 days off treatment cycle. The treatment was continued until study day 18 for the control and dose groups 10 and $20 \mathrm{mg} / \mathrm{kg}$, and terminated at day 20. The $40 \mathrm{mg} / \mathrm{kg}$ dose group was continued until study day 26 , and terminated at day 29. The treatment was compared to mice treated IV with paclitaxel ( $24 \mathrm{mg} / \mathrm{kg}$ ) once in a week until study day 22 . The tumor volume was measured at regular intervals (day 11, 13, $15,18,20,22,25$ and 28).

\section{Statistical analysis}

Statistical analyses were performed using paired two-tailed Student's $t$-test. Statistical significance was defined as $* P \leq 0.05, * * P \leq 0.01$ and $* * * P \leq 0.001$. Values are presented as the average \pm standard deviation (SD).

\section{Results and discussion \\ Pharmacokinetics, permeability and distribution of NOV202}

The pharmacokinetic profile of NOV202 was investigated after intravenous and oral administration in male $\mathrm{C} 57 \mathrm{Bl} / 6$ mice. The nominal dose was 10 and $30 \mathrm{mg} / \mathrm{kg}$ for IV and PO administration, respectively, and the actual concentration was determined to be 9.5 and $28.6 \mathrm{mg} / \mathrm{kg}$. The pharmacokinetics data are summarized in Table 1. The permeability of NOV202 was tested through Caco-2 monolayers in both the apicalto-basolateral and basolateral-to-apical directions. First, the compound passed the Lucifer yellow monolayer integrity test criteria $\left(<0.8 \times 10^{-6} \mathrm{~cm} / \mathrm{s}\right)$. The compound's permeability was ranked to be high and no significant efflux was observed (Table 2). The distribution of NOV202 in plasma and brain was determined in male $\mathrm{C} 57 \mathrm{Bl} / 6$ mice after IV and $\mathrm{PO}$ administrations at 2, 6 and $24 \mathrm{~h}$ post-dosing (Table 3). At the $2 \mathrm{~h}$ time-point the concentration of NOV202 in brain

Table I Pharmacokinetics of NOV202 in male C57BI/6 mice

\begin{tabular}{lll}
\hline Parameter & NOV202 IV & NOV202 PO \\
\hline Dose $(\mathrm{mg} / \mathrm{kg})$ & 9.5 & 28.6 \\
$\mathrm{C}_{\text {max }}(\mathrm{ng} / \mathrm{mL})$ & 1,775 & 406 \\
$\mathrm{~T}_{\max }(\mathrm{h})$ & 0.08 & 0.25 \\
$\mathrm{AUC}_{0-\mathrm{t}}(\mathrm{ng} \mathrm{h} / \mathrm{mL})$ & 1,423 & 1,576 \\
$\mathrm{AUC}_{0 \text {-inf }}(\mathrm{ng} \mathrm{h} / \mathrm{mL})$ & 1,485 & 1,607 \\
$\lambda_{\mathrm{z}}$ range $(\mathrm{h})$ & $2-10$ & $6-24$ \\
$\mathrm{t} 1 / 2 \mathrm{z}(\mathrm{h})$ & 2.4 & 4.8 \\
$\mathrm{Vd}(\mathrm{L} / \mathrm{kg})$ & 22 & - \\
$V_{s s}$ area $(\mathrm{L})$ & 16 & - \\
$\mathrm{CL}(\mathrm{L} / \mathrm{h} / \mathrm{kg})$ & 6.4 & - \\
Bioavailability $(\%)$ & 100 & 36 \\
based on AUC & &
\end{tabular}

Abbreviations: $\lambda$, terminal disposition rate constant/terminal rate constant; $t / 2 z$, terminal disposition rate constant/terminal rate constant half-life; Vd, apparent volume of distribution; Vss, apparent volume of distribution at steady state; CL, apparent total body clearance of the drug from plasma; AUC, area under the curve; $\mathrm{IV}$, intravenous; PO, oral. 
Table 2 Caco-2 permeability of NOV202

\begin{tabular}{lllll}
\hline Compound & $\begin{array}{l}\text { Caco-2, } \mathbf{P}_{\text {app }} \text { A-to-B } \\
\left(10^{-6} \mathbf{c m} / \mathbf{s}\right)\end{array}$ & $\begin{array}{l}\text { Caco-2, } \mathbf{P}_{\text {app }} \text { B-to-A } \\
\left(10^{-6} \mathbf{c m} / \mathbf{s}\right)\end{array}$ & $\begin{array}{l}\text { Permeability } \\
\text { classification }\end{array}$ & Efflux ratio \\
\hline NOV202 & $15.8 \pm 0.2$ & $16.1 \pm 2.2$ & High & 1.0 \\
\hline
\end{tabular}

Notes: Permeability coefficiency and efflux ratio of a bi-directional Caco-2 permeability assay. The data are from two biological replicates (mean \pm SD).

Abbreviation: SD, standard deviation.

markedly exceeded the plasma levels, indicating that the compound bypasses the blood-brain barrier and readily distributes into brain tissue. This suggests a possibility for the treatment of brain metastasis using NOV202. In conclusion, our data show that NOV202 has good pharmacokinetic properties and high cell permeability. To determine existence of possible sex differences in the pharmacokinetic profile of NOV202 we will extend the profiling to female mice in near future.

\section{Suppression of cell proliferation by NOV202}

A 3-day nonclonogenic microplate-based cell viability FMCA setup was used for the measurement of the cytotoxic and/or antiproliferative effect of NOV202 and reference compounds paclitaxel, vincristine and CYT997 in vitro. Quantification of the cell survival shows that the compound possesses strong antiproliferative impact on all cell lines tested. In the panel of six cell lines that were analyzed first, the $\mathrm{IC}_{50}$ values for NOV202 were between 3.9 and $12 \mathrm{nM}$ (Table 4). In order to study if NOV202 is a substrate for the Pgp/MDR1 efflux pump, the compound was evaluated in a pair of OC cell lines consisting of a drug sensitive parental A2780 and its multidrug-resistant subline A2780/Adr. Quantification of the FMCA data indicated that NOV202 was equally effective in suppressing cell proliferation in the drug resistant cells as the parental cells (Table 5); the ratio of $\mathrm{IC}_{50}$ values (A2780/Adr variant vs parental A2780) was 0.96 , indicating similar potency between the drug resistant and sensitive cells. Notably, the reference drugs paclitaxel, vincristine and CYT997 were found to be notably less

Table 3 The mean plasma and brain levels of NOV202

\begin{tabular}{clll}
\hline Route & Plasma $(\mathbf{n g} / \mathbf{m L})$ & Brain $(\mathrm{ng} / \mathrm{g})$ & Plasma:brain ratio \\
\hline PO & & & \\
$2 \mathrm{~h}$ & 329 & 589 & 1.8 \\
$6 \mathrm{~h}$ & $6 \mathrm{I}$ & $\mathrm{NA}$ & - \\
$24 \mathrm{~h}$ & $\mathrm{NA}$ & $\mathrm{NA}$ & - \\
$\mathrm{IV}$ & & & \\
$2 \mathrm{~h}$ & 246 & $\mathrm{I}, 667$ & 6.8 \\
$6 \mathrm{~h}$ & 58 & NA & - \\
$24 \mathrm{~h}$ & $\mathrm{NA}$ & $\mathrm{NA}$ & - \\
\hline
\end{tabular}

Notes: The data are from three biological replicates. NA, the concentration was below the limit of reliable quantification ( $<25 \mathrm{ng} / \mathrm{g}$ in brain).

Abbreviations: IV, intravenous; NA, not available; PO, oral. effective in inducing cell killing in the drug resistant variant cell line as compared to the parental cell line; the $\mathrm{IC}_{50}$ values were 810, 210 and $183 \mathrm{nM}$, and $\mathrm{IC}_{50}$ ratios 3,115, 955 and 3.35 for paclitaxel, vincristine and CYT997 in the A2780/ Adr cells, respectively (Table 5). We conclude that NOV202 suppresses cell proliferation of various cancer cell lines of different tissue origin at low nanomolar concentrations. Moreover, the compound appears not to be a substrate of the Pgp/MDR1 efflux pump, which would be a significant clinical advance in comparison to paclitaxel in the treatment of OC patients with advanced or recurring disease.

\section{NOV202 induces $M$ phase arrest and cell death in dividing cancer cells}

The M phase effects of NOV202 were investigated in a several human cancer cell lines of different origin. Paclitaxel, vinblastine and epothilone-B were used as reference compounds. First, HCT116, HCT8, and MCF10A cells cultured in the presence of NOV202 $(50 \mathrm{nM})$ or a reference compound ( $50 \mathrm{nM}$ ) were time-lapse filmed for 3 days immediately after supplementation of the culture medium with a drug. Cell population growth curvatures were determined using the IncuCyte software based on the cell confluency. The analysis showed strong growth suppression in all three cell lines treated with NOV202, which was comparable to the efficacy of paclitaxel, vinblastine and epothilone-B (Figure 1A). From the same time-lapse videos we also measured the length of $\mathrm{M}$ phase arrest and recorded the fate of 30 mitotic cells for each cell line treated with the compounds at $50 \mathrm{nM}$ concentration. As expected, treatment of cells with NOV202 caused a transient mitotic delay that lasted for several hours; the average duration of mitosis in HCT116, HCT8 and MCF10A cell lines was $26.2 \pm 7.1 \mathrm{~h}, 11.8 \pm 3.1 \mathrm{~h}$ and 16.4 $\pm 5.2 \mathrm{~h}$, respectively (Figure 1B), which all were significantly longer than in the vehicle-treated controls $(P<0.001)$. Similarly, treatment of HCT116, HCT8 and MCF10A cells with paclitaxel, vinblastine or epothilone-B induced a long $\mathrm{M}$ phase arrest that was comparable to the NOV202 treatment (Figure 1B). The HCT116 cells that have an intact mitotic checkpoint $^{18}$ and normal $\mathrm{p} 53$ response ${ }^{19}$ exhibited onefold longer $\mathrm{M}$ phase arrest upon the compound treatments when compared to the HCT8 cells (Figure 1B). Also, the fate of the mitotically arrested cells was found to be different between 
Table 4 Antiproliferative activity $\left(\mathrm{IC}_{50}, \mathrm{nM}\right)$ of NOV202 and reference compounds in various cancer cell lines

\begin{tabular}{|c|c|c|c|c|c|}
\hline Cell line & Disease & NOV202 & PTX & VinC & CYT997 \\
\hline BXPC-3 & Pancreatic adenocarcinoma & 8.0 & 4.0 & 2.0 & 37.1 \\
\hline CCRF-CEM & Acute lymphoblastic leukemia & 10.0 & NA & 10.4 & 3.6 \\
\hline HCTII6 & Colorectal carcinoma & 9.2 & 1.9 & 1.7 & 47.7 \\
\hline HT29 & Colorectal adenocarcinoma & 3.9 & 3.5 & 0.4 & 39.3 \\
\hline RPM 18226 & Multiple myeloma & 12.0 & NA & 17.9 & 18.3 \\
\hline U-937 & Histiocytic lymphoma & 8.0 & NA & 7.6 & 33.1 \\
\hline
\end{tabular}

Abbreviations: NA, not available; PTX, paclitaxel; VinC, vincristine; CYT997, lexibulin.

HCT116 and HCT8 cells; half or more of the HCT116 cells died from the $\mathrm{M}$ phase arrest although the majority of the HCT8 cells underwent mitotic slippage (Figure 1C). The fate of nontransformed MCF10A cells resembled more that of the HCT116 cells than HCT8 cells (Figure 1C).

Next, we determined the CDI from the IncuCyte films for each treatment at 24 and $48 \mathrm{~h}$ time points using morphological criteria of apoptosis such as cell rounding and condensation, plasma membrane blebbing and cytosolic vacuolization..$^{20}$ Quantification of the results indicated a significant increase in cell death by the compounds $(50 \mathrm{nM})$ at both time points in each cell line in comparison to controls ( $P \leq 0.001$, Figure 1D). Especially, at the $48 \mathrm{~h}$ time point the frequency of cell death was massive; the HCT116 cells were the most sensitive and exhibited an average CDI between $57 \%$ and $72 \%$ pending on the treatment while the MCF $10 \mathrm{~A}$ cells were the least sensitive of the three cell lines showing an average CDI between $40 \%$ and $49 \%$ pending on the compound (Figure 1D). Finally, the MI was determined from cell samples that were fixed and DNA stained at 24 and $48 \mathrm{~h}$ time points posttreatment and imaged using HC-fluorescent microscope enabling accurate identification of mitotic cells based on chromatin condensation. As expected, at the $24 \mathrm{~h}$ time point the average MI was significantly elevated in each compound treated cell line $(50 \mathrm{nM})$ in comparison to the respective DMSO control ( $P \leq 0.001$, Figure 1E) while at the $48 \mathrm{~h}$ time point the average MI was only between $1 \%$ and $12 \%$ due to the high cytotoxicity of the compounds. The data show that NOV202 treatment phenocopies typical cellular effects of microtubule targeting drugs in vitro. Indeed, $50 \mathrm{nM}$

Table $5 \mathrm{IC}_{50}$-values (nM) and ratios of NOV202 and reference compounds in drug sensitive and resistant ovarian carcinoma cell lines

\begin{tabular}{lllll}
\hline Cell line & NOV202 & PTX & VinC & CYT997 \\
\hline A2780 (drug sensitive) & 2.40 & 0.26 & 0.22 & 54.60 \\
A2780/Adr (drug resistant) & 2.30 & 810 & 210 & 182.70 \\
IC $_{50}$ ratio & 0.96 & 3,115 & 955 & 3.35 \\
(resistant vs sensitive cells) & & & & \\
\hline
\end{tabular}

Abbreviations: PTX, paclitaxel; VinC, vincristine; CYT997, lexibulin.
NOV202 had equal efficacy as paclitaxel in each three cell lines. The compound induces a long-lasting $\mathrm{M}$ phase arrest that in the mitotic checkpoint efficient cells is followed by death of the arrested cells and in the checkpoint deficient cells by death of interphase cells after mitotic slippage. At this time, no additional cell cycle perturbing impacts were observed, which suggests that the compound has very little, if any, off-target effects in cultured cancer cells.

\section{Effects of NOV202 in different OC cell lines}

To analyze the effects of NOV202 in OC models in vitro we selected three OC cell lines that according to our earlier data exhibit different response to microtubule targeting agents (unpublished data, M Kallio, personal communication, August 2015). Ovarian adenocarcinoma OvCar-8, OvCar-4 and $\mathrm{CaOv}-3$ cells cultured in the presence of $12.5 \mathrm{nM}$ of NOV202 or $12.5 \mathrm{nM}$ of paclitaxel were time-lapse filmed for 3 days immediately after supplementation of the culture medium with a drug (Figure S1). Control cells were treated with the vehicle only. The MI and CDI were determined from the time-lapse films at 12, 24, 48 and $72 \mathrm{~h}$ time points. The ovarian adenocarcinoma OvCar- 8 and OvCar-4 cells responded moderately to the NOV202 treatment $(12.5 \mathrm{nM})$ and exhibited a peak $27.0 \% \pm 4.0 \%$ and $24.0 \% \pm 9.5 \% \mathrm{MI}$ at $12 \mathrm{~h}$ time point, respectively (Figure 2A). This was significantly more in comparison to the vehicle-treated control cells exhibiting MI of $6.7 \% \pm 1.2 \%$ and $5.3 \% \pm 2.5 \%$ at $12 \mathrm{~h}$ time point, respectively $(P<0.001)$. In the later time points, the MI of NOV202 treated OvCar-8 and OvCar-4 cell populations dropped dramatically that was likely due to the short transient $\mathrm{M}$ phase arrest and increasing cell death. In contrast, the ovarian adenocarcinoma $\mathrm{CaOv}-3$ cells exhibited much lower MI as only $12.7 \% \pm 2.5 \%$ and $7.6 \% \pm 2.9 \%$ of the cells were at $\mathrm{M}$ phase arrest after $12 \mathrm{~h}$ treatment with $12.5 \mathrm{nM}$ NOV202 or DMSO, respectively (Figure 2A). Overall the results were similar after treatment of the three cell lines with $12.5 \mathrm{nM}$ paclitaxel (Figure 2A); OvCar-8 and OvCar-4 cells exhibited a moderate mitotic arrest at $12 \mathrm{~h}$ time point while 
A
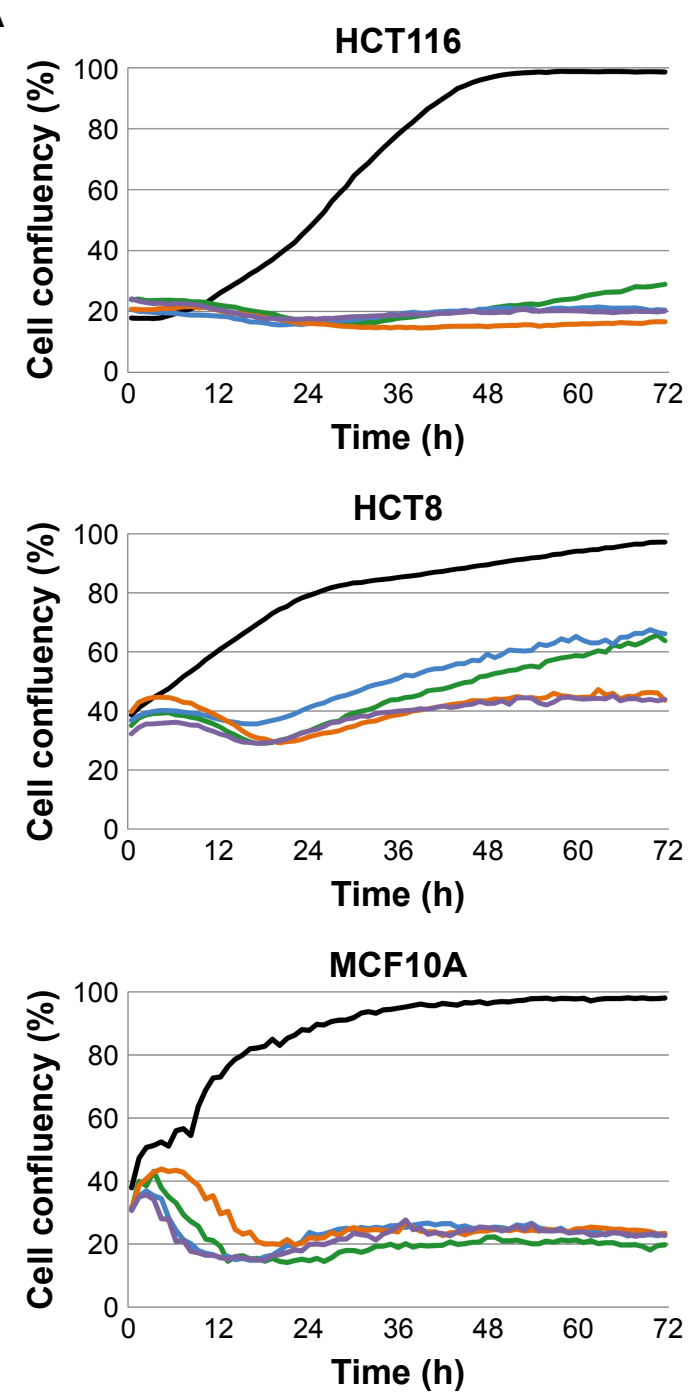

\begin{tabular}{|ll|}
\hline - DMSO & - NOV202 $50 \mathrm{nM}-$ PTX $50 \mathrm{nM}$ \\
- VBL $50 \mathrm{nM}$ & - EpoB $50 \mathrm{nM}$
\end{tabular}

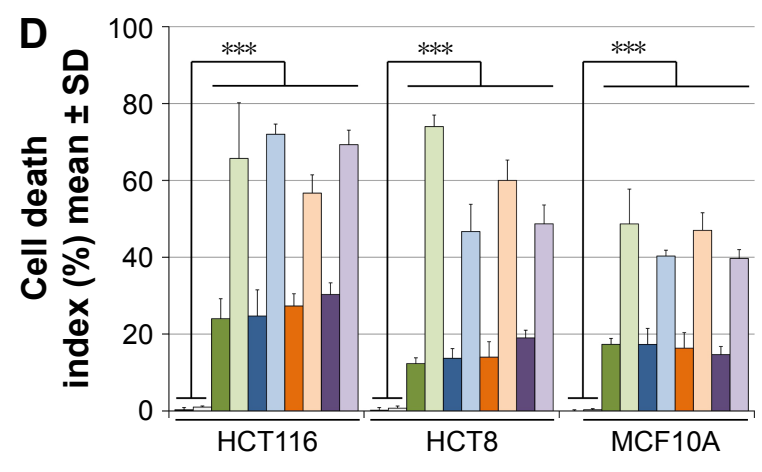

DMSO $24 \mathrm{~h} \quad \square$ DMSO $48 \mathrm{~h} \quad \square$ NOV202 $24 \mathrm{~h}$

PTX $48 \mathrm{~h} \square$ VBL $24 \mathrm{~h} \square$ VBL $48 \mathrm{~h}$

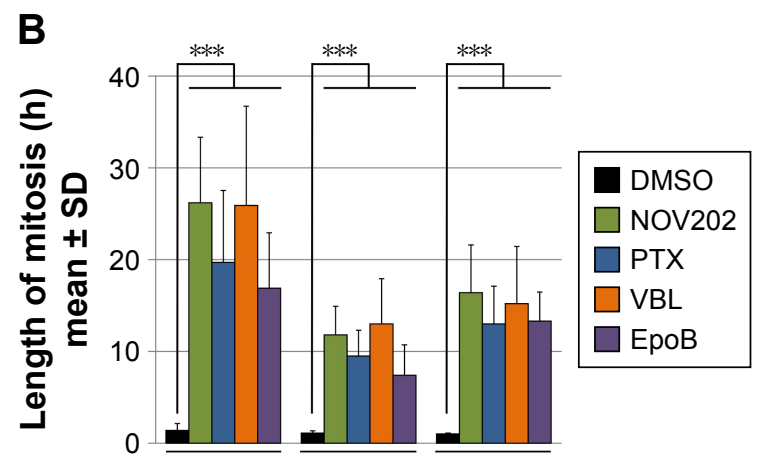

C

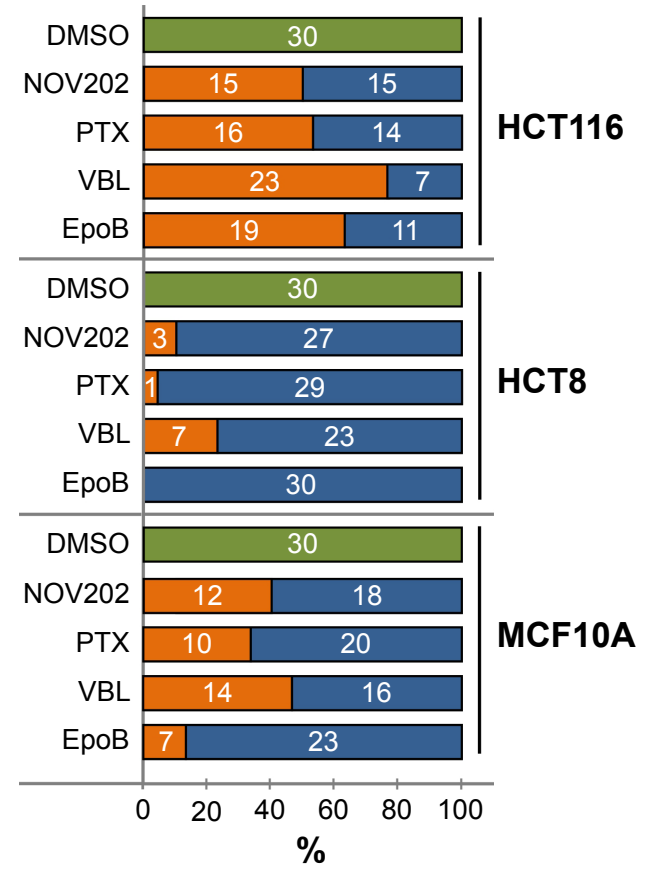

Normal cell division

Cell death from mitosis

Mitotic slippage

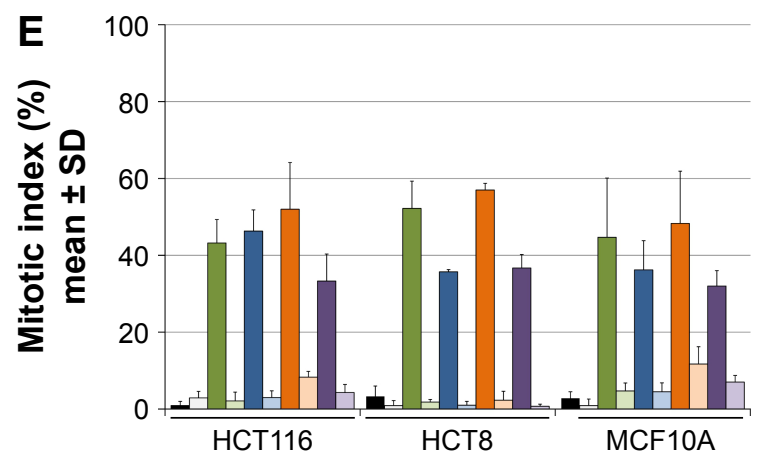

Figure I Analysis of NOV202 and reference compound effects on viability and mitotic fate of human HCTII6, HCT8 and MCFIOA cells in vitro.

Notes: The cell confluency measurements (A) indicate clear growth suppression by the $50 \mathrm{nM}$ concentration of NOV202 and reference drugs. Analysis of mitotic duration (B) shows that all compounds induce a long-lasting mitotic arrest. The fate of drug-treated mitotic cells (C) varies in a cell line dependent manner. All drug treatments significantly increased frequency of cell death $(\mathbf{D})$ at each analysis time point and elevated the mitotic indices (E), especially at the $24 \mathrm{~h}$ time point. $* * *$ Statistical significance of $P \leq 0.00$ I.

Abbreviations: DMSO, dimethyl sulfoxide; EpoB, epothilone-B; PTX, paclitaxel; VBL, vinblastine. 


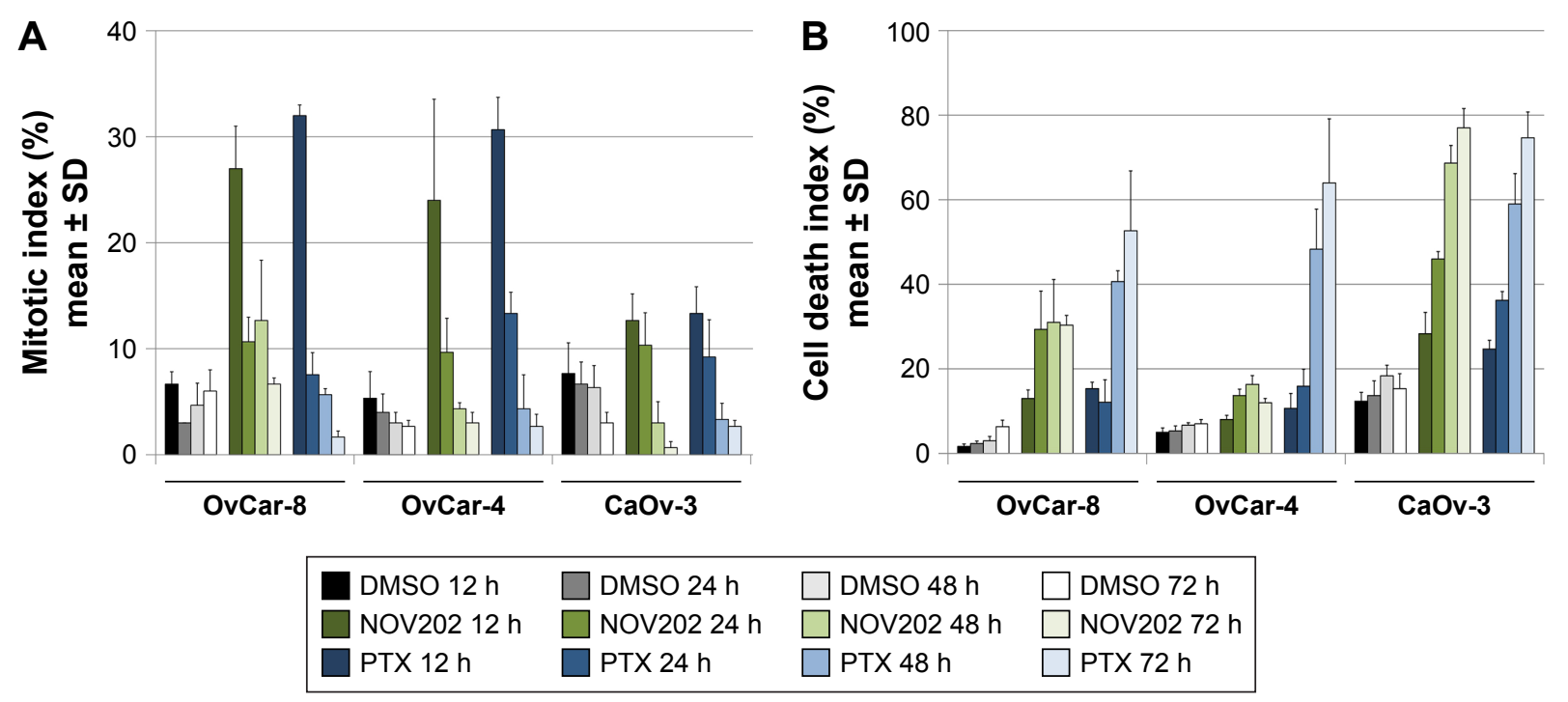

Figure 2 Analysis of NOV202 and reference compounds effects on cell death and mitotic indices in ovarian carcinoma cell lines.

Notes: Treatment of OvCar-8, OvCar-4 and CaOv-3 cells with $12.5 \mathrm{nM}$ NOV202 elevated markedly the frequencies of mitotic cells (A) at 12 and $24 \mathrm{~h}$ time points and increased cell death (B) at 24, 48 and $72 \mathrm{~h}$ time points in comparison to DMSO.

Abbreviations: DMSO, dimethyl sulfoxide; PTX, paclitaxel.

the $\mathrm{CaOv}-3$ cells did not markedly accumulate to $\mathrm{M}$ phase (Figure 2A).

Also, the fate of the mitotic cells varied markedly between the three cell lines and drug treatments. The average frequency of cell death started to rise significantly $(P<0.001)$ in OvCar-8 $(29.0 \% \pm 9.0 \%)$ and $\mathrm{CaOv}-3$ cells $(46.0 \% \pm 1.7 \%) 24 \mathrm{~h}$ after the treatment with $12.5 \mathrm{nM}$ of NOV202 in comparison to the controls $(2.3 \% \pm 0.6 \%$ and $13.7 \% \pm 2.5 \%$, respectively, Figure $2 \mathrm{~B}$ ). However, the OvCar-4 cells survived much better than the NOV202 treatment as only $13.7 \% \pm 1.5 \%$ of the cells were dead at the $24 \mathrm{~h}$ time point in comparison to the CDI of $5.3 \% \pm 1.1 \%$ in the controls (Figure 2B). At the 48 and $72 \mathrm{~h}$ time points the average CDI remained high in the NOV202-treated OvCar-8 (31.0\% $\pm 10.5 \%$ and $30.0 \% \pm 2.3 \%$, respectively) and $\mathrm{CaOv}-3$ cells $(68.7 \% \pm 4.2 \%$ and $77.0 \% \pm 4.6 \%$, respectively) while in the OvCar-4 cells CDI remained low $(16.3 \% \pm 2.1 \%$ and $12.0 \% \pm 1.0 \%$, respectively, Figure 2B). Moreover, the OvCar- 4 cells were more sensitive to $12.5 \mathrm{nM}$ of paclitaxel at 48 and $72 \mathrm{~h}$ time points when compared to same concentration of NOV202 (Figure 2B). It should, however, be noted that OvCar- 4 cells treated with a higher $50 \mathrm{nM}$ concentration of NOV202 underwent a massive cell death; at 24, 48 and $72 \mathrm{~h}$ time points the average CDI was $28.7 \% \pm 6.8 \%$, $48.3 \% \pm 10.7 \%$ and $59.3 \% \pm 13.2 \%$, respectively. Treatment of OvCar- 8 and $\mathrm{CaOv}-3$ cells with $12.5 \mathrm{nM}$ of paclitaxel resulted in CDI profiles that closely resembled the outcome of exposure to $12.5 \mathrm{nM}$ of NOV202 (Figure 2B). Finally, the three cell lines were also subjected to a combination treatment with NOV202 and paclitaxel but no synergistic effects were observed when compared to single drug dosing (data not shown). We conclude that NOV202 and paclitaxel possess similar capacity to induce $\mathrm{M}$ phase arrest in different OC cell lines but the outcome of the cell cycle delay varies in a cell line dependent manner. The data reflect underlying high heterogeneity of OC cancer lines and tumors, which causes challenges in the treatment of patients. In future, the clinical decision making on OC chemotherapy could benefit from the assessment of ovarian tumor cells' mitotic checkpoint activity prior to drug selection and start of the treatments.

\section{NOV202 inhibits tubulin polymerization} in vitro in a dose-dependent manner

NOV202 was designed to interfere with the colchicine binding site of $\alpha$-tubulin and thereby suppresses the microtubule dynamics by inhibiting tubulin polymerization. The observations made in cultured human cells support the notion that the compound perturbs normal microtubule dynamics and cause a cell cycle arrest at $\mathrm{M}$ phase. To confirm the mechanism of action of NOV202 in vitro the compound was tested in cell-free tubulin polymerization assay. Paclitaxel and vincristine were used as controls with known high tubulin affinity. NOV202 was found to suppress tubulin heterodimer polymerization to microtubules at $3.0 \mu \mathrm{M}$ concentration similar to $3.0 \mu \mathrm{M}$ of vincristine (Figure 3). At the $10 \mu \mathrm{M}$ concentration NOV202 was sufficient to block the polymerization almost completely while at $1.0 \mu \mathrm{M}$ concentration the compound slowed down 


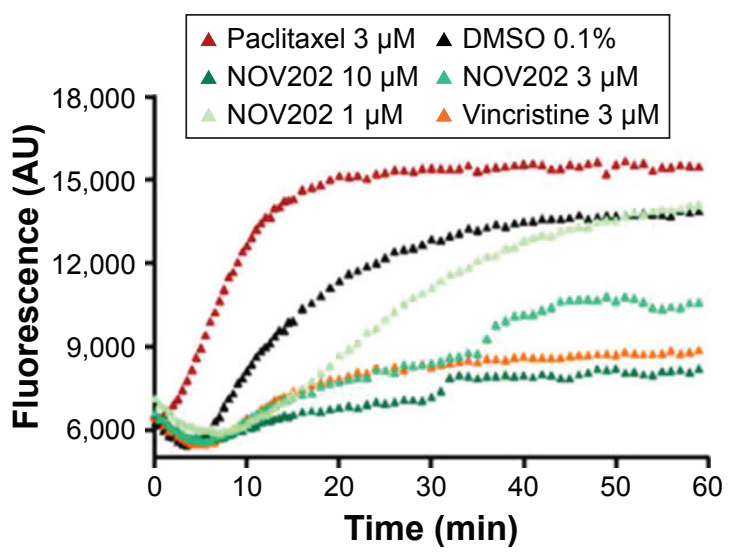

Figure 3 Effect of NOV202 on tubulin polymerization in vitro.

Notes: Data from a representative tubulin polymerization assay indicating the suppressive potency of NOV202 at $\mathrm{I}-10 \mu \mathrm{M}$ concentrations. Vincristine and paclitaxel were used as positive controls at $3 \mu \mathrm{M}$ concentration for tubulin polymerization inhibition and stabilization, respectively.

Abbreviation: DMSO, dimethyl sulfoxide.

the rate of the polymerization, but could not suppress it. As expected, paclitaxel was an effective stabilizer of tubulin polymerization at the $3.0 \mu \mathrm{M}$ concentration tested. The effects of NOV202 on interphase and mitotic microtubules were confirmed to be very robust in cultured HCT116, HCT8 and MCF10A cells; the microtubule networks were markedly disrupted or completely wiped out after exposure to low 15-50 nM concentrations of NOV202 (data not shown). We conclude that NOV202 efficiently perturbs normal tubulin polymerization in vitro and in cells.

\section{NOV202 perturbs vascular cord} formation and disrupts established cord structures equally to Combretastatin A4

A number of experimental tubulin inhibitors as, for example, Combretastatin A4 (fosbretabulin), CYT997 and ENMD1198 have been reported to exhibit antiangiogenetic and/or vascular disrupting effects. ${ }^{21-23}$ To determine the potential impact of NOV202 on tumor vasculature in vitro we used cocultures of human endothelial colony forming cells and adipose-derived stem cells. The impacts of NOV202, Combretastatin A4 and suramin, a known inhibitor of VEGF, on vascular cord formation and preformed cord structures were measured on VEFG stimulated cocultures (Figure 4,
A

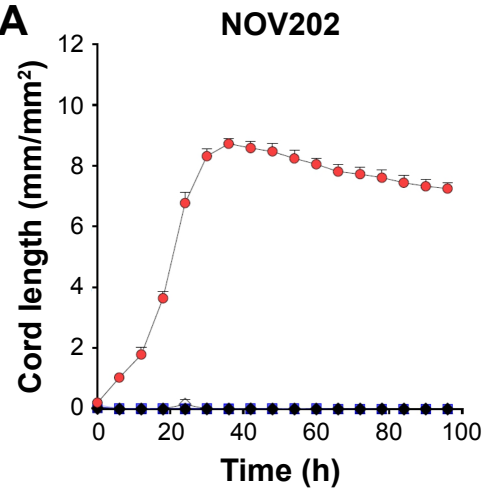

$4.6 \mathrm{nM} \square 41.2 \mathrm{nM} \triangle 0.37 \mu \mathrm{M}$ $\bigcirc 13.7 \mathrm{nM} \square 0.12 \mathrm{nM} \triangle 1.11 \mu \mathrm{M}$

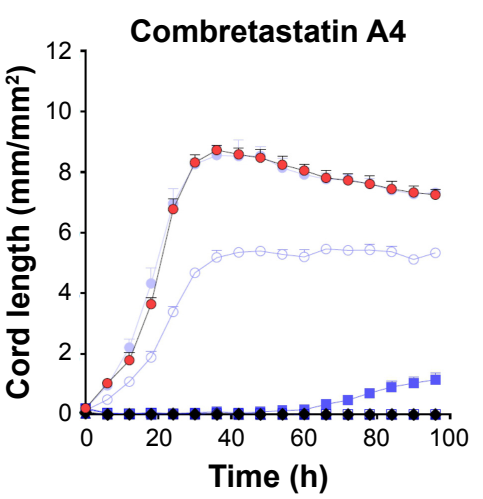

$0.78 \mathrm{nM} \square 3.13 \mathrm{nM} \triangle 12.5 \mathrm{nM}$ $1.56 \mathrm{nM} \square 6.25 \mathrm{nM} \triangle 25.0 \mathrm{nM}$

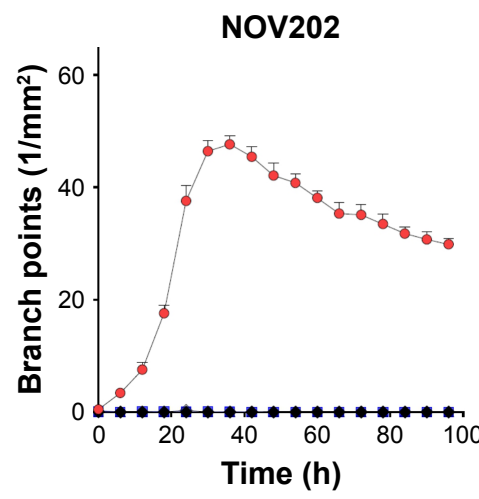

VEGF $(20 \mathrm{ng} / \mathrm{mL})+$ $0.1 \%$ DMSO

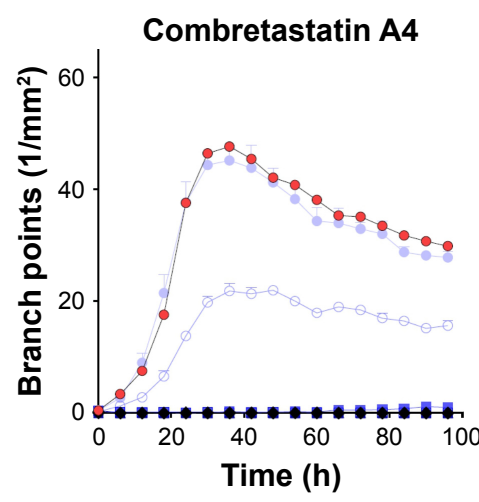

Time (h)
B
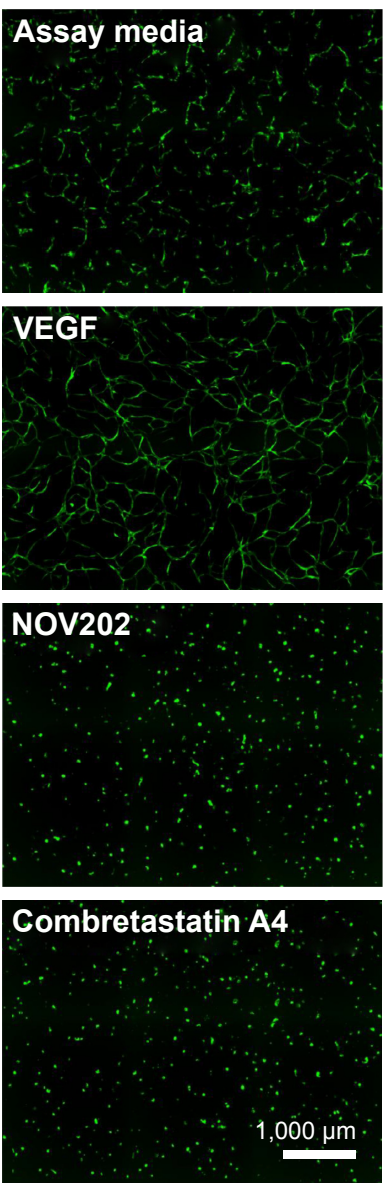

Figure 4 (Continued) 

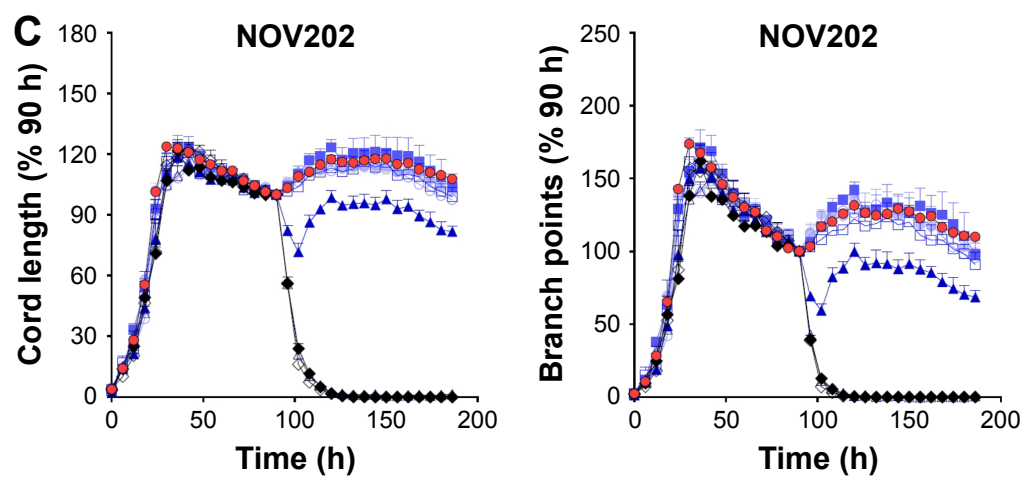

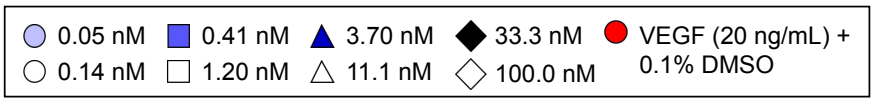
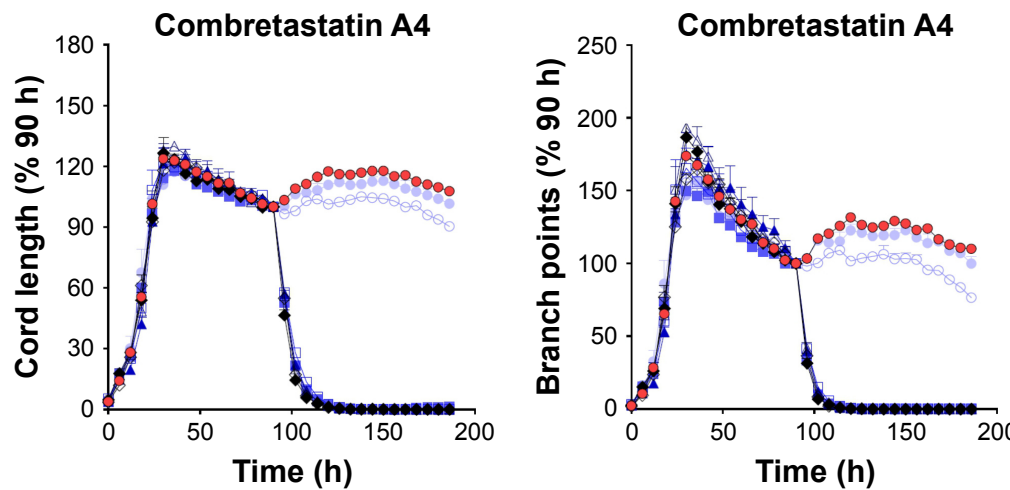

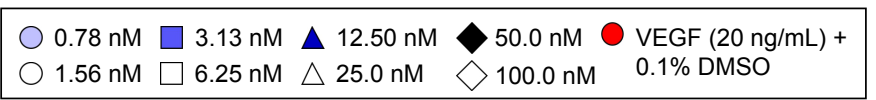

D
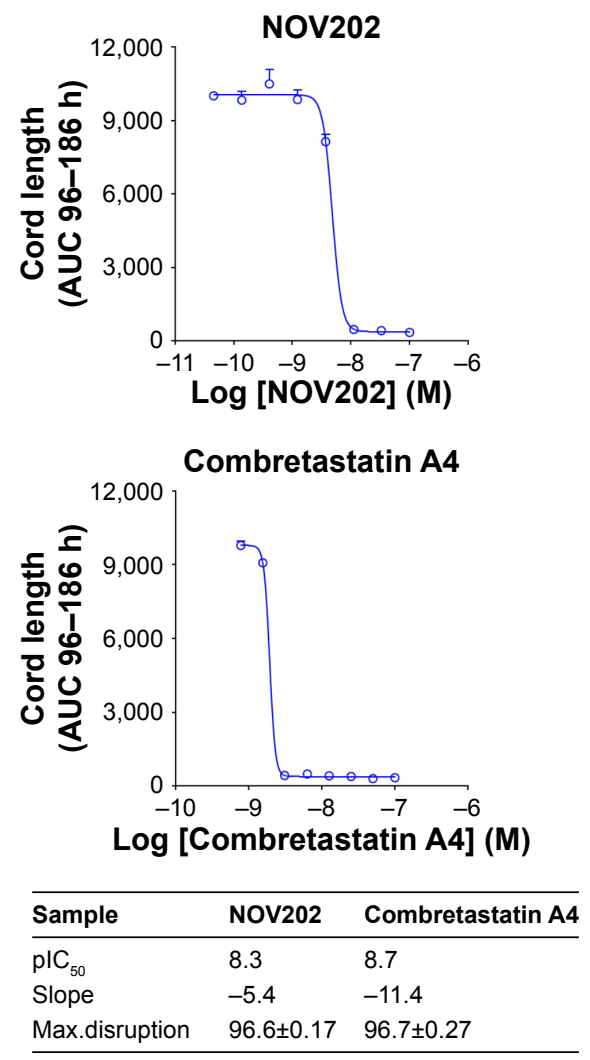

Figure 4 Inhibitory effects of NOV202 on endothelial cell cord formation and disruption in vitro.

Notes: (A) Over the entire concentration range (4.6 nM-10 $\mu \mathrm{M})$, NOV202 suppressed completely the VEGF-induced cord formation determined as relative cord length (left hand diagram) and branching (right hand diagram). Combretastatin A4, a known inhibitor of angiogenesis, was equally effective at concentrations above 6.0 nM. (B) Representative micrographs for assay media control, VEGF $(20 \mathrm{ng} / \mathrm{mL})$, NOV202 (I.I $\mu \mathrm{M})$ and Combretastatin A4 (0.I $\mu$ M)-treated cells. The scale bar equals I,000 $\mu \mathrm{m}$. (C) Disruption of established cords by NOV202 and Combretastatin A4 determined as relative cord length (left hand diagrams) and branch points (right hand diagrams). The drugs were added at $96 \mathrm{~h}$ time point. (D) Concentration response curves for NOV202 and Combretastatin A4 caused disruption of VEGF stimulated established cords. The table shows $\mathrm{PIC}_{50}$, Hill coefficient (slope) and maximal cord disruption (\%) values that were determined for each replicate with respect to the maximal control VEGF (20 $\mathrm{ng} / \mathrm{mL}$ ) response. For the controls see also Figure S2.

Abbreviations: AUC, area under curve; VEGF, vascular endothelial growth factor; $\mathrm{plC}_{50},-\log 10\left(\mathrm{IC}_{50}\right)$.

for controls see Figure S2). In the presence of basal media, a peak mean cord length of $4.1 \pm 0.8 \mathrm{~mm} / \mathrm{mm}^{2}$ and a peak mean branch point of $17.5 \pm 3.8 \mathrm{~mm} / \mathrm{mm}^{2}$ were observed (Figure S2). Addition of VEGF (20 ng/mL +0.1\% DMSO) increased the peak mean cord length to $8.7 \pm 0.5 \mathrm{~mm} / \mathrm{mm}^{2}$ and peak mean branch point to $47.6 \pm 4.4 \mathrm{~mm} / \mathrm{mm}^{2}$ (Figures S2 and 4A). NOV202 was found to completely inhibit tube formation at the lowest $4.6 \mathrm{nM}$ concentration tested (Figure 4A). This effect was comparable to the Combretastatin A4 treatment (Figure 4A). For the established cords, the presence of assay media alone yielded a peak mean cord length of $5.2 \pm 0.1 \mathrm{~mm} / \mathrm{mm}^{2}$ and a peak mean branch point of $21.9 \pm 1.2 \mathrm{~mm} / \mathrm{mm}^{2}$ (Figure S2) VEGF $(20 \mathrm{ng} / \mathrm{mL}+0.1 \%$ DMSO) evoked a rapid time-dependent formation of vascular cords, as evidenced by an increase in the peak mean cord length and peak mean branch points $\left(9.6 \pm 0.4 \mathrm{~mm} / \mathrm{mm}^{2}\right.$ and $58.4 \pm 4.4 \mathrm{~mm} / \mathrm{mm}^{2}$, respectively, Figure S2). Cord formation stabilized around the $120 \mathrm{~h}$ time point (data not shown). NOV202 (0.046-100 nM) and Combretastatin A4 $(0.78-100 \mathrm{nM})$ both caused a concentration dependent disruption of cords with maximal cord disruption (>96\%) observed at the highest concentration tested (Figure 4C). A four-parameter logistic fit of the area under the curve data between 96 and $186 \mathrm{~h}$ time point gave $\mathrm{pIC}_{50}$ values of 8.3 and 8.7 for NOV202 and Combretastatin A4, respectively (Figure 4D). Importantly, despite the significant impact on cord formation and cord structures the viability of the endothelial colony forming cells and adipocyte derived stem cells was not impaired by the NOV202, Combretastatin A4 and control treatments (Figure 4B, Figure S3). 


\section{NOV202 shows antiangiogenesis effects in the chicken embryo CAM assay}

An ex ovo chick CAM assay was employed to confirm the observed antivascular effect of NOV202 in vitro. Analysis of the developing blood vessel in the chick embryos indicated that growth of the blood vessels, determined as change in the relative surface area of blood vessels, and the vascular integrity, determined as discontinuity of the vessels, were both significantly suppressed by $50 \mathrm{nM}$ NOV202 and $50 \mathrm{nM}$ Combretastatin A4 at 24 and $48 \mathrm{~h}$ time points posttreatment in comparison to controls (Figure 5A-C). At the $10 \mathrm{nM}$ concentration both drugs were ineffective when compared to DMSO vehicle.

\section{NOV202 shows high in vivo efficacy in OC xenograft model}

Encouraged by the in vitro results we next determined the in vivo efficacy of NOV202 using an ovarian carcinoma
A2780 xenograft model. First, in the study of maximum tolerated dose the plasma concentration at the dose $40 \mathrm{mg} / \mathrm{kg}$ was determined to be $309 \mathrm{nM}$ at $1 \mathrm{~h}$ and $76 \mathrm{nM}$ at $4 \mathrm{~h}$ postdosing, at the dose $20 \mathrm{mg} / \mathrm{kg} ; 54$ and $29 \mathrm{nM}$, and at the dose $10 \mathrm{mg} / \mathrm{kg} ; 21$ and $17 \mathrm{nM}$, respectively. As shown in Figure 6A, NOV202 caused a dose-dependent reduction in tumor volume, and at the highest dose $(40 \mathrm{mg} / \mathrm{kg})$ a clear antitumor effect that was comparable to the impact generated with paclitaxel at $24 \mathrm{mg} / \mathrm{kg}$. At day 20 the antitumor effect was $83 \%$ compared to control group determined as reduced relative tumor volume. NOV202 was well tolerated during the treatment as determined by the body weight measurements (Figure 6B). We conclude that NOV202 exerts a clear inhibition of A2780 tumor growth at the highest dose, comparable to the inhibitory effect of paclitaxel. Notably, NOV202 was administered PO and paclitaxel IV, which shows the outstanding effects of this candidate drug. The $\mathrm{IC}_{50}$ value of NOV202 in the A2780 OC cell line was 2, $4 \mathrm{nM}$
A

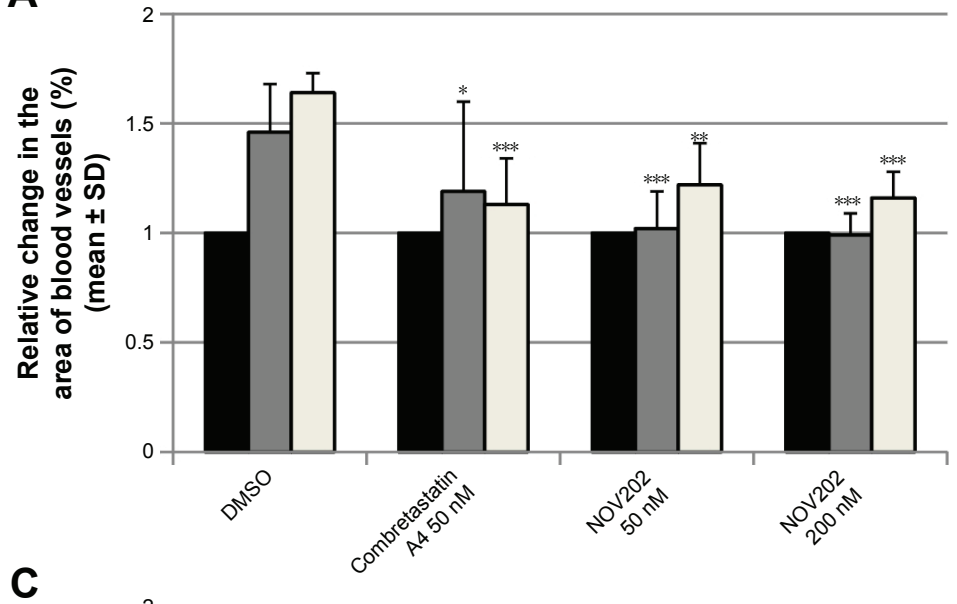

C

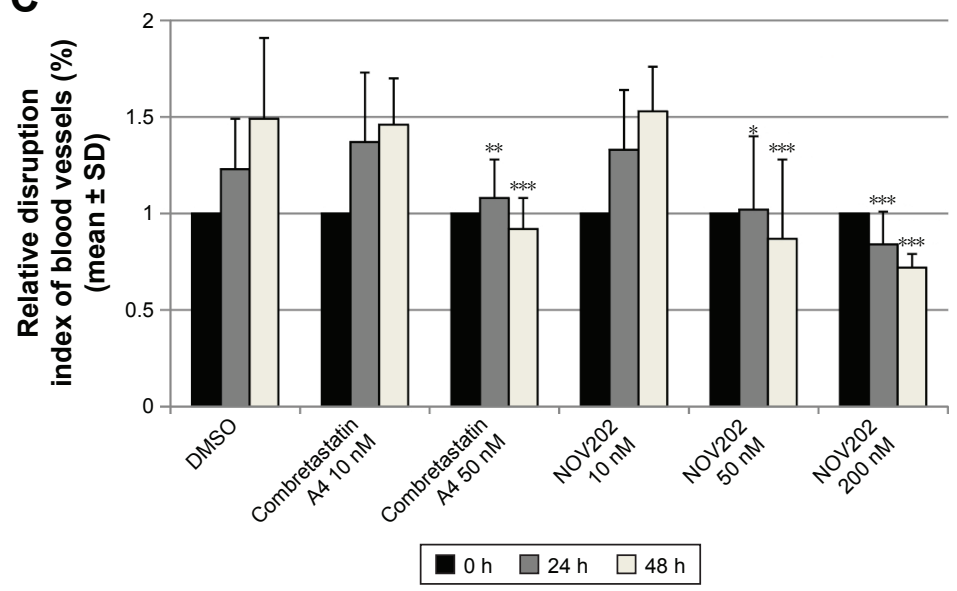

B

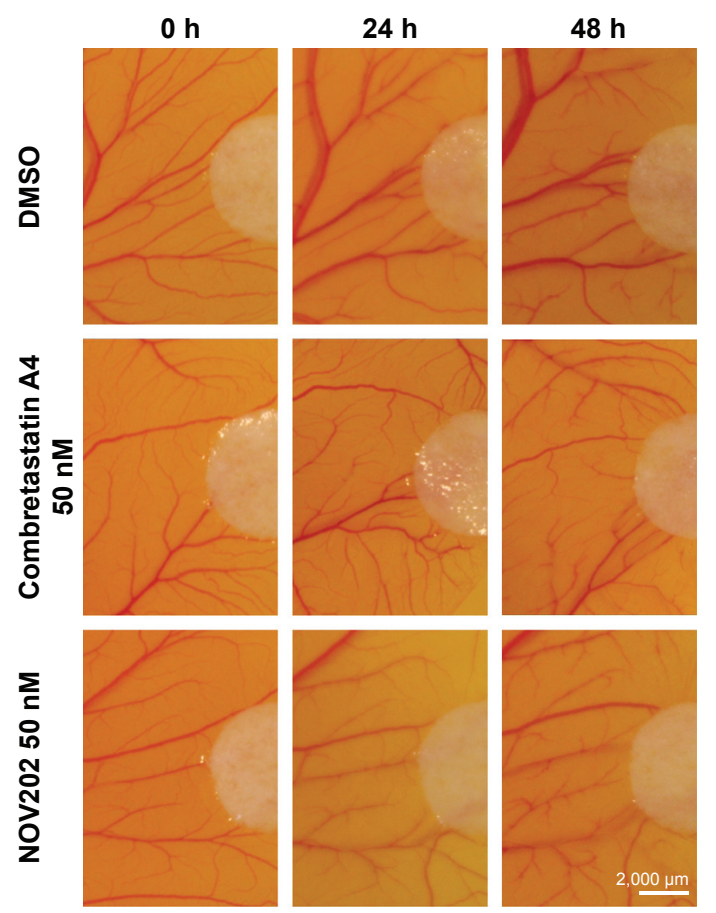

Figure 5 Effects of NOV202 on developing blood vessels of chick embryo.

Notes: (A) A $50 \mathrm{nM}$ NOV202 suppressed significantly the growth of the blood vessels at 24 and $48 \mathrm{~h}$ time points in comparison to controls. The antivascular impact of NOV202 was comparable to Combretastatin A4. (B) Representative micrographs showing the developing blood vessels for DMSO, NOV202 and Combretastatin A4-treated eggs. The white half-circles are the paper filters housing the experimental compounds. (C) Breakage of existing chick embryo blood vessels by NOV202 and Combretastatin A4. The scale bar equals $2,000 \mu \mathrm{m}$. *, **, and *** denote statistical significances of $P \leq 0.05, P \leq 0.0 \mathrm{I}$ and $P \leq 0.00 \mathrm{I}$, respectively.

Abbreviations: DMSO, dimethyl sulfoxide; SD, standard deviation. 

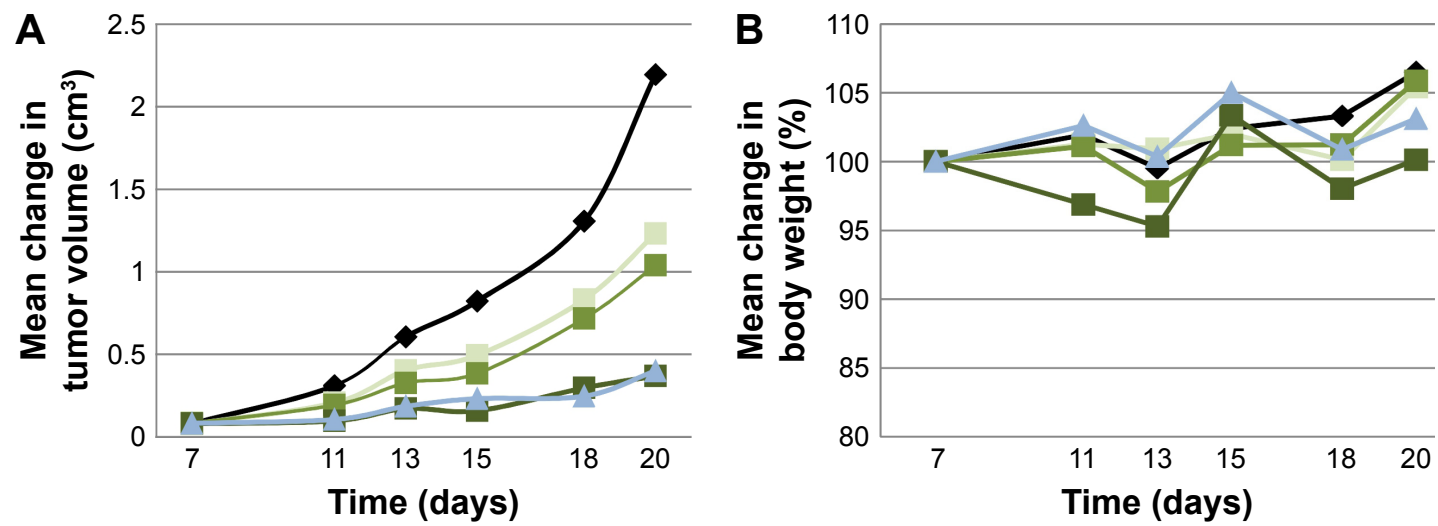

$\begin{array}{ll}\text { Vehicle control } & \text { NOV202 } 10 \mathrm{mg} / \mathrm{kg}(\mathrm{PO})-\mathrm{NOV} 20220 \mathrm{mg} / \mathrm{kg}(\mathrm{PO}) \\ -\mathrm{NOV} 20240 \mathrm{mg} / \mathrm{kg}(\mathrm{PO})-\text { PTX } 24 \mathrm{mg} / \mathrm{kg}(\mathrm{IV})\end{array}$

Figure 6 In vivo efficacy of NOV202 on A2780 xenograft model and impact on body weight of NMRI nu/nu female nude mice.

Notes: (A) NOV202 induced a clear reduction in the volume of A2780 tumors in comparison to controls. (B) The NOV202 therapy was well tolerated according to the body weight measurements.

Abbreviations: IV, intravenous; PTX, paclitaxel; NMRI, Naval Medical Research Institute; PO, oral administration.

and therefore the plasma concentration in the efficacy study, especially at the $40 \mathrm{mg} / \mathrm{kg}$ dose, should be high enough for a potent reduction of tumor volumes in vivo, as shown in Figure 6A. The effect of NOV202 in multidrug resistant cells and the possible reduced toxicity is a key advantage of NOV202 and warrants further development of this anticancer compound toward the clinic.

\section{Conclusion}

Tubulin targeting agents are widely used as antineoplastic drugs. Their optimal efficacy is, however, often compromised by the dose-limiting adverse effects and intrinsic/ acquired drug resistance. By the development of NOV202 we aimed at overcoming one or more of these issues. The compound displayed a significant antitumor activity in vitro against a panel of human cancer cells of different origin. Importantly, the multidrug-resistant A2780/Adr cells were highly sensitive to the growth suppression by low concentrations of NOV202, which is a significant advance over the current first-line chemotherapeutic paclitaxel. In vivo, NOV202 induced marked tumor growth retardation in an A2780 xenograft model with good tolerability. The efficacy of the compound in other cancer models such as breast cancer will be explored in further studies. Interestingly, the compound exhibited a strong antiangiogenic and vascular disrupting action in vitro and in CAM assay ex vivo, which likely contributes to its antineoplastic efficacy Agents with vascular disrupting properties represent a new class of promising anticancer agents, which exhibit synergistic and/or additive effects in combination with many conventional cytotoxics. Novel combinations need to be explored in the clinic with a strong focus on finding optimal mixture of antivascular agents and other small molecule anticancer drugs, as well as, combinations with anticancer biologics. One of the biggest advantages of these agents, including NOV202, over commonly used chemotherapeutics is their ability to bind reversibly to the colchicine binding pocket, which reduces their toxicity. Our data suggest that NOV202 presents a promising approach for the treatment of refractory OC.

\section{Disclosure}

SR and $\mathrm{MH}$ are employees and shareholders in Noviga Research AB. The authors report no other conflicts of interest in this work.

\section{References}

1. Howlader N, Noone AM, Krapcho M, et al. SEER Cancer Statistics Review, 1975-2011, National Cancer Institute. Bethesda, MD. Available from: http://seer.cancer.gov/csr/1975_2011/ based on 2013 SEER data submission. Accessed June 10, 2016.

2. Schorge JO, Modesitt SC, Coleman RL, et al. SGO White Paper on ovarian cancer: etiology, screening and surveillance. Gynecol Oncol. 2010; 119(1):7-17.

3. Jordan MA, Wilson L. Microtubules as a target for anticancer drugs. Nat Rev Cancer. 2004;4(4):253-265.

4. Schwartz EL. Antivascular actions of microtubule-binding drugs. Clin Cancer Res. 2009;15(8):2594-2601.

5. McGuire WP, Rowinsky EK, Rosenhein NB, et al. Taxol: a unique antineoplastic agent with significant activity in advanced ovarian epithelial neoplasms. Ann Intern Med. 1989;111(4):273-279.

6. Sledge GW Jr, Robert N, Sparano JA, et al. Paclitaxel (Taxol)/ doxorubicin combinations in advanced breast cancer: the Eastern Cooperative Oncology Group experience. Semin Oncol. 1994;21(5 Suppl 8): 15-18. 
7. Bonomi P, Kim KB, Kugler J. Comparison of survival for stage IIIB versus stage IV non-small cell lung cancer (NSCLC) patients with etoposide-cisplatin versus taxol-cisplatin: an Eastern Cooperative Oncology Group (ECOG) trial. Proc Am Soc Clin Oncol. 1997;16:454a.

8. Vasey PA, Jayson GC, Gordon A, et al; Scottish Gynaecological Cancer Trials Group. Phase III randomized trial of docetaxel-carboplatin versus paclitaxel-carboplatin as first-line chemotherapy for ovarian carcinoma. J Nat Cancer Inst. 2004;96(22):1682-1691.

9. Davidson B, Tropé CG. Ovarian cancer: diagnostic, biological and prognostic aspects. Womens Health (Lond). 2014;10(5):519-533.

10. Gottesman MM, Fojo T, Bates SE. Multidrug resistance in cancer: role of ATP-dependent transporters. Nat Rev Cancer. 2002;2(1):48-58.

11. Thomas H, Coley HM. Overcoming multidrug resistance in cancer: an update on the clinical strategy of inhibiting p-glycoprotein. Cancer Contl. 2003;10(2):159-165.

12. Mickisch GH, Merlino GT, Galski H, Gottesman MM, Pastan I. Transgenic mice that express the human multidrug-resistance gene in bone marrow enable a rapid identification of agents that reverse drug resistance. Proc Natl Acad Sci U S A. 1991;88(2):547-551.

13. Ambudkar SV, Dey S, Hrycyna CA, Ramachandra M, Pastan I, Gottesman MM. Biochemical, cellular, and pharmacological aspects of the multidrug transporter. Ann Rev Pharmacol Toxicol. 1999;39: 361-398.

14. Palmeira A, Sousa E, Vasconcelos MH, Pinto MM. Three decades of P-gp inhibitors: skimming through several generations and scaffolds. Curr Med Chem. 2012;19(13):1946-2025.
15. Jang SH, Wientjes MG, Au JL. Kinetics of P-glycoprotein-mediated efflux of paclitaxel. J Pharmacol Exp Ther. 2001;298(3):1236-1242.

16. Dohle DS, Pasa SD, Gustmann S, et al. Chick ex ovo culture and ex ovo CAM assay; how it really works. J Vis Exp. 2009;33:e1620.

17. Lindhagen E, Nygren P, Larsson R. The fluorometric microculture cytotoxicity assay. Nat Protoc. 2008;3(8):1364-1369.

18. Tighe A, Johnson VL, Albertella M, Taylor SS. Aneuploid colon cancer cells have a robust spindle checkpoint. EMBO Rep. 2001;2(7): 609-614.

19. Waldman T, Kinzler KW, Vogelstein B. p21 is necessary for the p53mediated G1 arrest in human cancer cells. Cancer Res. 1995;55(22): 5187-5190.

20. Loo DT, Rillema JR. Measurement of cell death. Methods Cell Biol. 1998;57:251-264

21. Galbraith SM, Chaplin DJ, Lee F, et al. Effects of combretastatin A4 phosphate on endothelial cell morphology in vitro and relationship to tumour vascular targeting activity in vivo. Anticancer Res. 2001;21(1A): 93-102.

22. Burns CJ, Fantino E, Phillips ID, et al. CYT997: a novel orally active tubulin polymerization inhibitor with potent cytotoxic and vascular disrupting activity in vitro and in vivo. Mol Cancer Ther. 2009;8(11): 3036-3045.

23. Pasquier E, Sinnappan S, Munoz MA, Kavallaris M. ENMD-1198, a new analogue of 2-methoxyestradiol, displays both antiangiogenic and vascular-disrupting properties. Mol Cancer Ther. 2010;9(5): 1408-1418. 


\section{Supplementary materials}
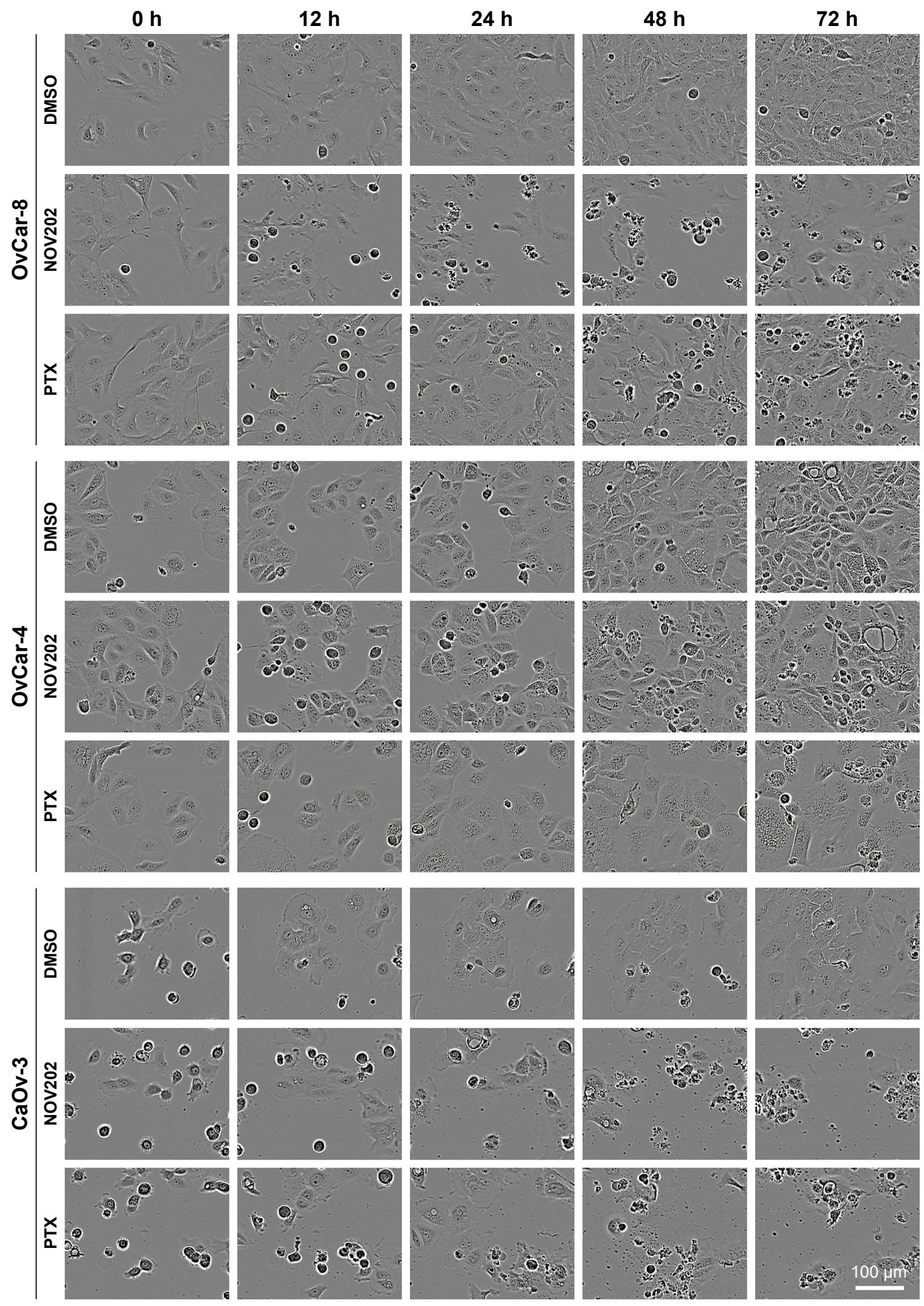

Figure SI Cell population growth suppression by NOV202 and PTX in OC cell lines in vitro.

Notes: Representative images of OvCar-8, OvCar-4 and CaOv-3 cells cultured in the presence of $12.5 \mathrm{nM}$ NOV202 or $12.5 \mathrm{nM}$ PTX. The scale bar equals I,000 $\mu \mathrm{m}$. Abbreviations: DMSO, dimethyl sulfoxide; OC, ovarian cancer; PTX, paclitaxel. 

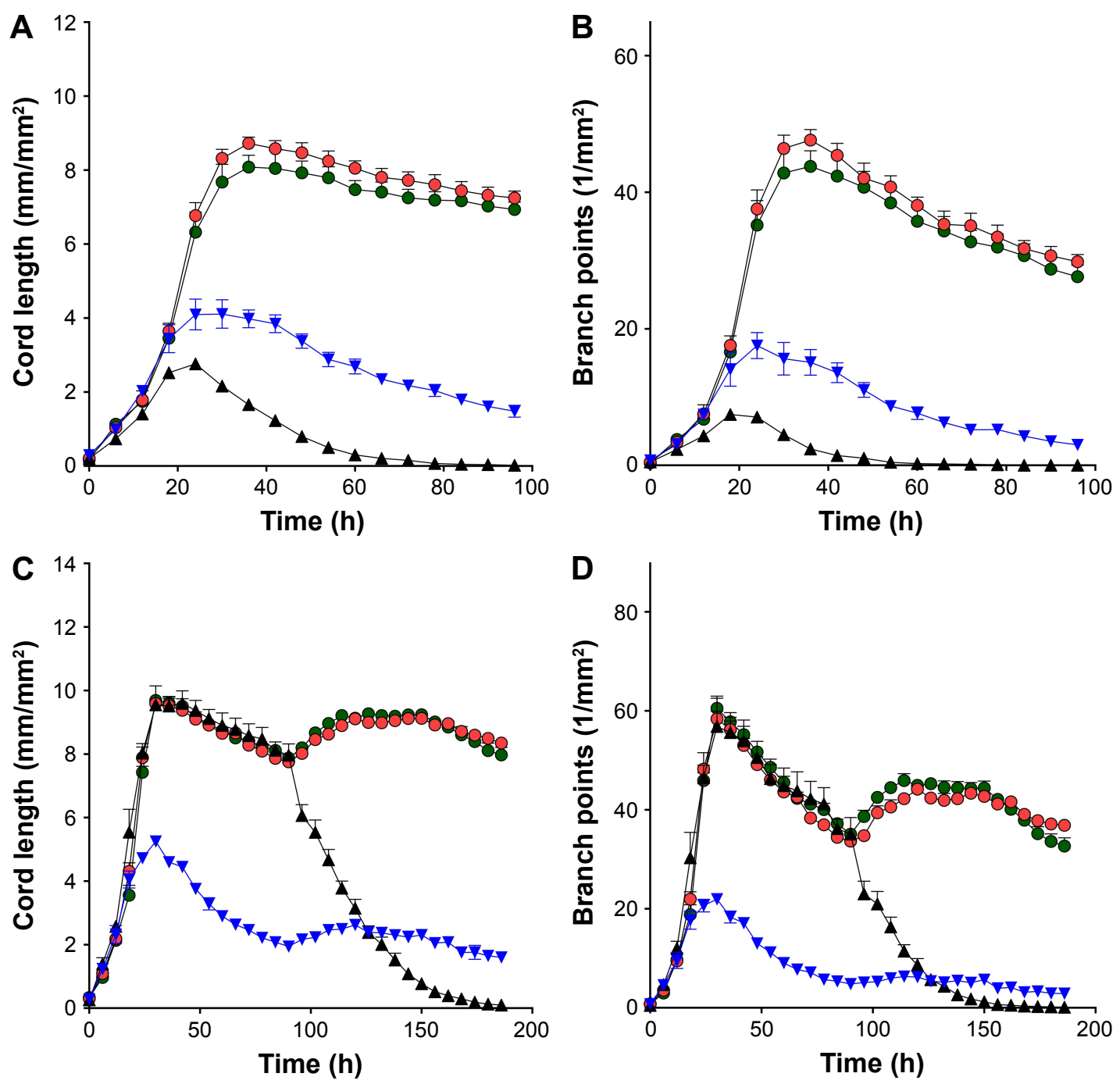

VEGF $(20 \mathrm{ng} / \mathrm{mL}) \quad-$ - VEGF $(20 \mathrm{ng} / \mathrm{mL})+0.1 \%$ DMSO $\_$VEGF $+\operatorname{suramin}(100 \mu \mathrm{M})$

$\checkmark$ Media

Figure S2 Neoangiogenic and established cord formation control data.

Notes: Time-courses of $(\mathbf{A})$ neoangiogenic cord length and $(\mathbf{B})$ branch point values ( $\mathrm{n}=4-8$ per assay point). Samples were first added at $\mathrm{t}=0 \mathrm{~h}$ ( $4 \mathrm{~h}$ post coculture creation). Suramin $(100 \mu M)$, a known VEGF inhibitor, markedly attenuated the formation of cords. Time-courses of established cord length $(\mathbf{C})$ and branch point $(\mathbf{D})$ values $(\mathrm{n}=4-8$ per assay point). Samples were first added at $\mathrm{t}=96 \mathrm{~h}$. Addition of suramin ( $100 \mu \mathrm{M})$ resulted in complete regression of established cords.

Abbreviations: DMSO, dimethyl sulfoxide; VEGF, vascular endothelial growth factor. 

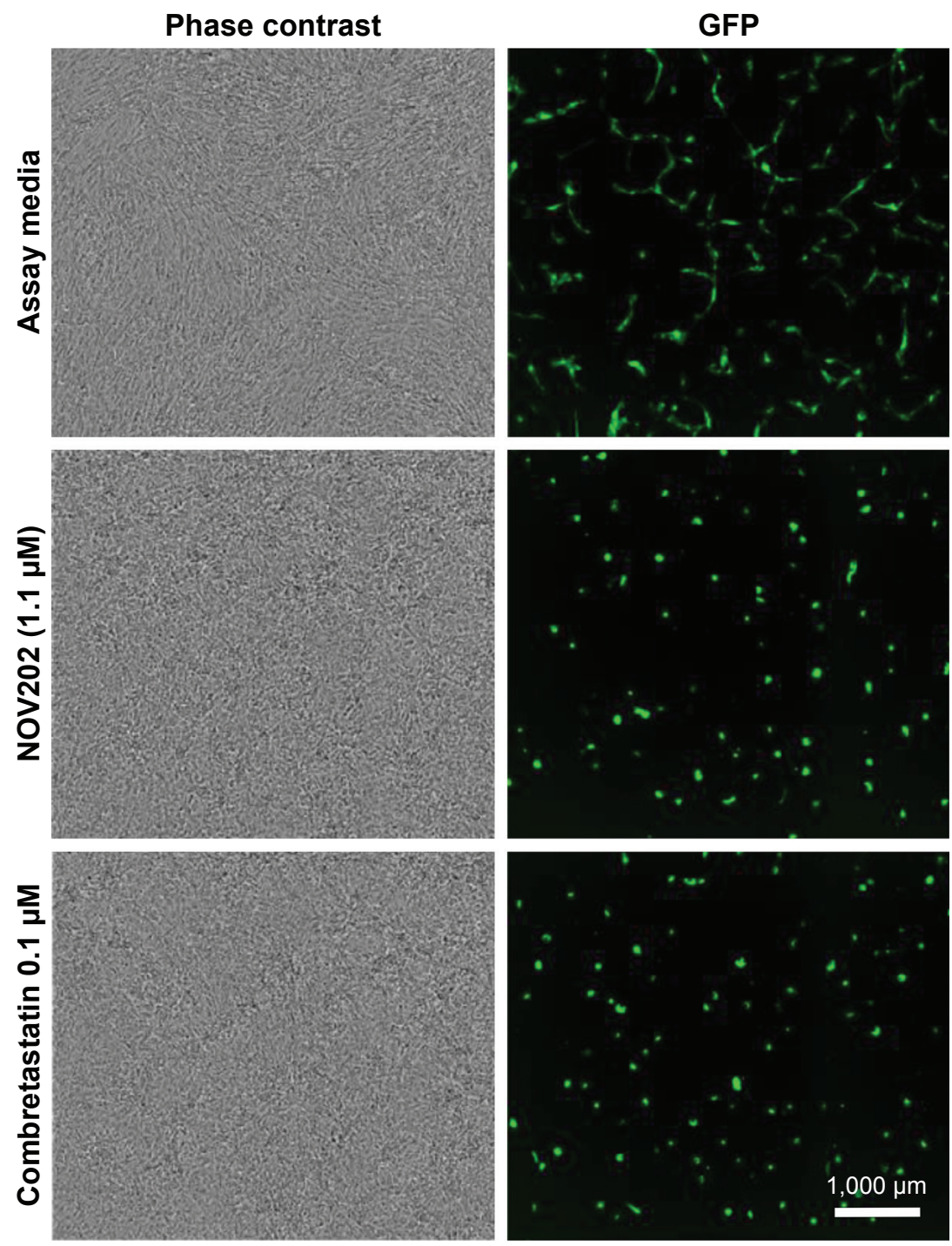

Figure S3 High concentrations of NOV202 and Combretastatin A4 inhibit VEGF-induced cord formation without impairing cell viability.

Notes: Representative phase contrast and fluorescence micrographs showing the impact of the two compounds on endothelial cell cord structures and survival of cocultured cells. The images were taken $72 \mathrm{~h}$ posttreatment. The scale bar equals $1,000 \mu \mathrm{m}$.

Abbreviations: GFP, green fluorescent protein; VEGF, vascular endothelial growth factor.

\section{Publish your work in this journal}

Drug Design, Development and Therapy is an international, peerreviewed open-access journal that spans the spectrum of drug design and development through to clinical applications. Clinical outcomes, patient safety, and programs for the development and effective, safe, and sustained use of medicines are the features of the journal, which has also been accepted for indexing on PubMed Central. The manuscript management system is completely online and includes a very quick and fair peer-review system, which is all easy to use. Visit http://www.dovepress.com/testimonials.php to read real quotes from published authors.

Submit your manuscript here: http://www.dovepress.com/drug-design-development-and-therapy-journal 